Portland State University

PDXScholar

1970

\title{
The 1958 Good Offices Mission and Its Implications for French-American Relations Under the Fourth Republic
}

Lorin James Anderson

Portland State University

Follow this and additional works at: https://pdxscholar.library.pdx.edu/open_access_etds

Part of the Diplomatic History Commons, European History Commons, and the United States History Commons

Let us know how access to this document benefits you.

\section{Recommended Citation}

Anderson, Lorin James, "The 1958 Good Offices Mission and Its Implications for French-American Relations Under the Fourth Republic" (1970). Dissertations and Theses. Paper 1468.

https://doi.org/10.15760/etd.1467

This Thesis is brought to you for free and open access. It has been accepted for inclusion in Dissertations and Theses by an authorized administrator of PDXScholar. Please contact us if we can make this document more accessible: pdxscholar@pdx.edu. 
AN ABSTRACT OF THE THESIS OF Lorin James Anderson for the Master of Arts in History presented November 30, 1970.

Title: The 1958 Good Offices Mission and its Inplications for French-Americen Kelations Under the Fourth ilepublic.

APPROVED BY MEMBERS OF THL THESIS COMHTTEE:

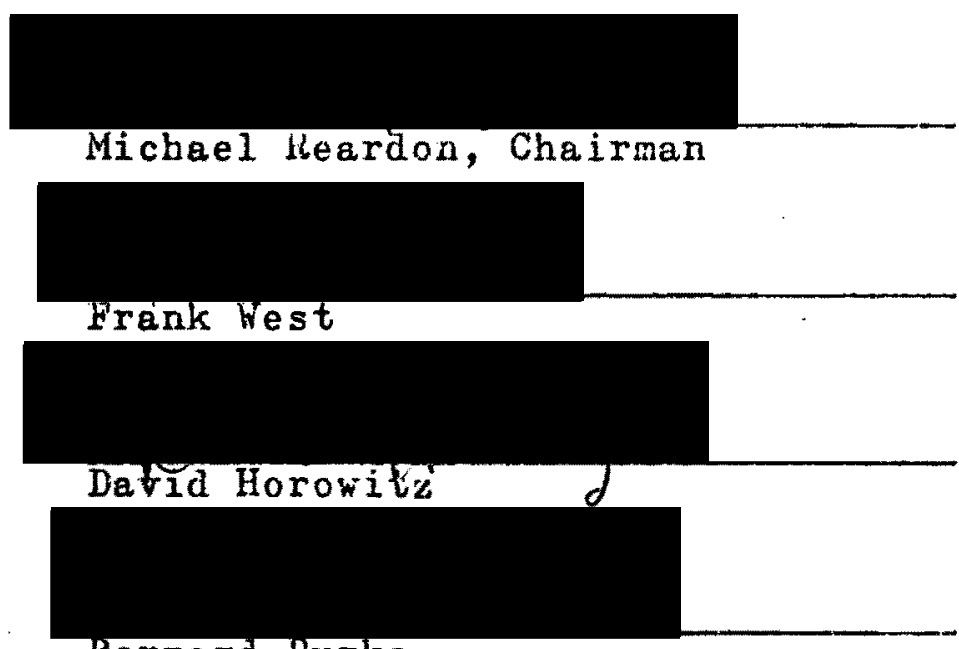

Bernard Burke

In both a general review of Franco-American relations and in a more specific discussion of the AngloAmerican good offices mission to France in 1958, this thesis has attempted first, to analyze the foreign policies of France and the United States which developed from the impact of the Second World War and, second, to describe Franco-American discord as primarily a collision of foreign policy goals--or, even farther, as a basic collision in the national attitudes 
that shaped those goals--rather than as a result either of Communist harassment or of the clash of personalities. 
TO THE OFFICE OF GHADUATE STUDIES:

The members of the Committee approve the

thesis of Lorin James Anderson.

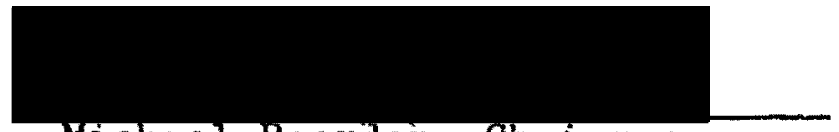

Michael Reardon, Chairman

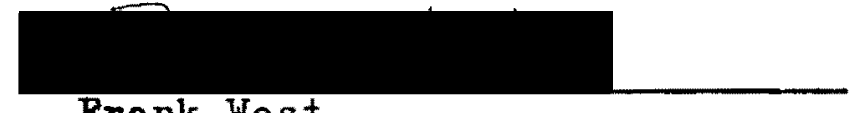

Prank West
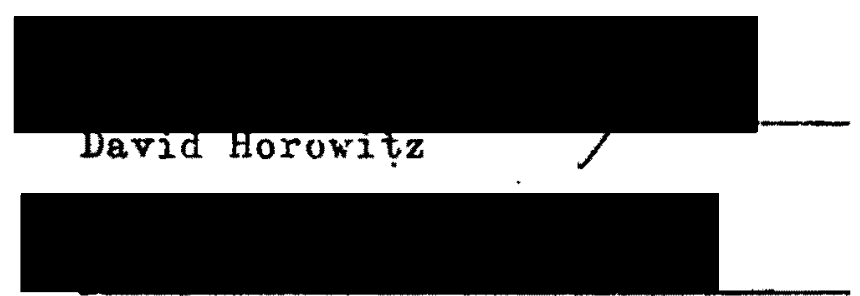

Bernard Burke

APPROVED :
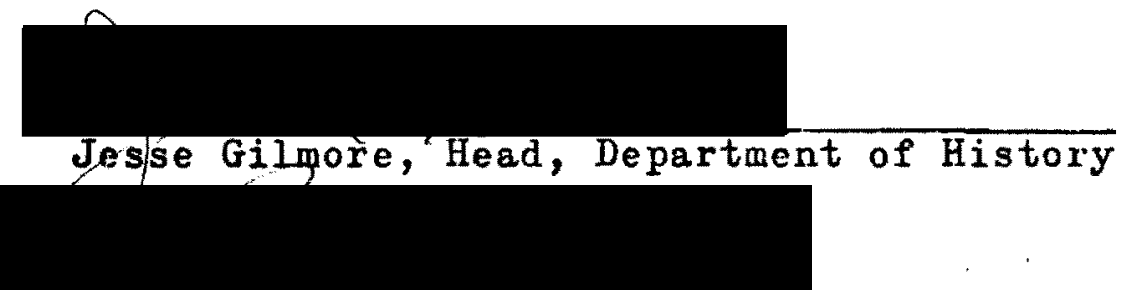

David Clark, Dean of Graduate Studies 
THE 1958 GOOD OFPICES MISSION AND ITS IMPLICATIONS FOR FRENCH-AMERICAN RELATIONS UNDRR THE FOURTH REPUBLIC

\author{
by \\ LORIN JAMES ANDERSON
}

A thesis submitted in partial fulfillment

of the requirements for the degree of
MASTEK OF ARTS
in
HISTORY

Portland State University

1970 
TABLE OF CONTIANTS

PAGE

CHAPTER

I INTRODUCTION . . . . . . . . . . 1

II FRANCE AND THE MODEIR CHALLENGE . . . . 4

III THE GOOD OFFICES MISSION OF 1958 . . $\quad 34$

IV DE GAULlE RETURNS . . . . . . . . . 72

A SELECTED BIBLTOGRAPHY . . . . . . . . . . 92

APPENDIX ........................ 98

LETTER OF :

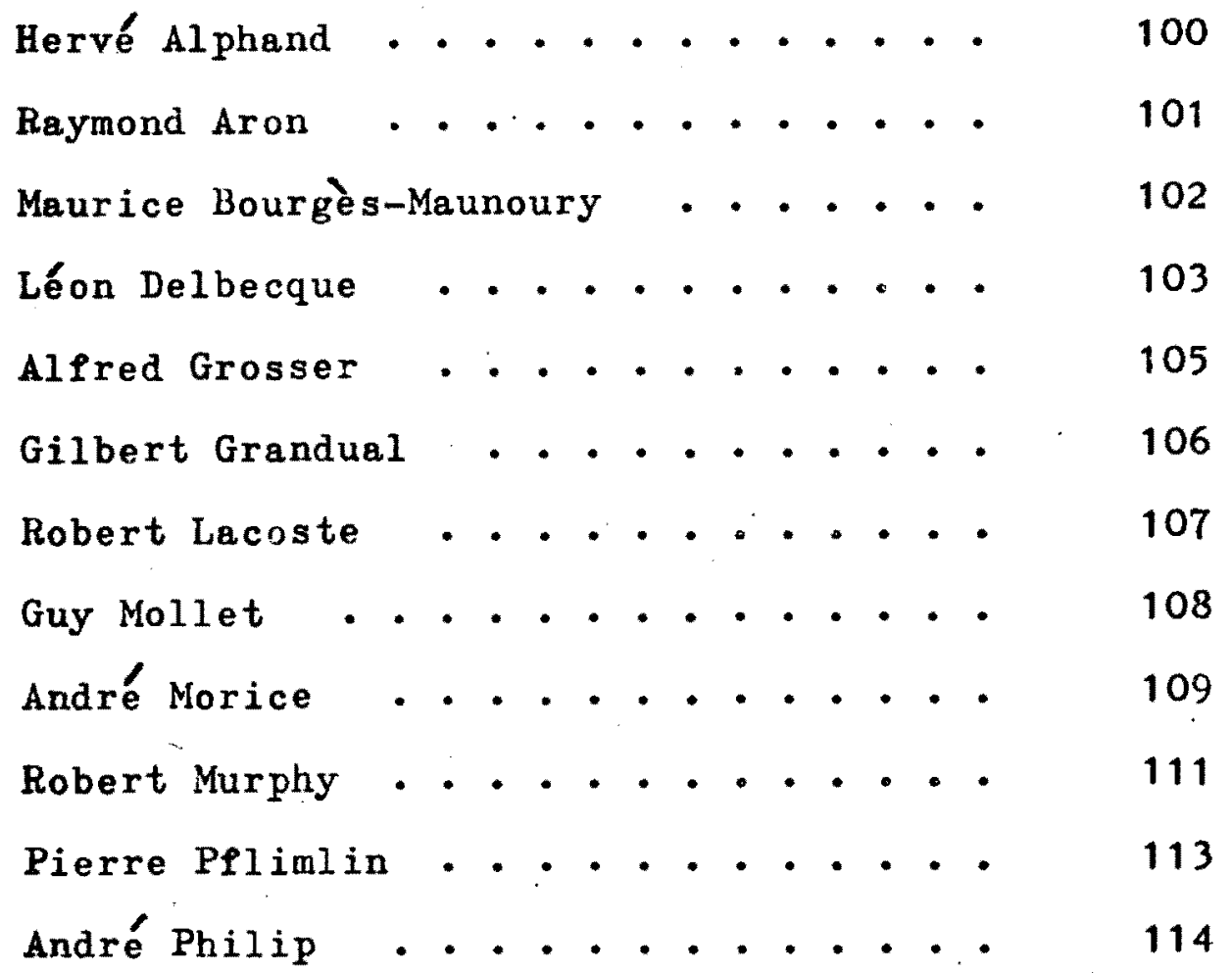


Christian Pineau

Jacque Soustelle 
CHAPTER I

\section{INTRODUCTION}

This paper developed from the topic considered in the third chapter--the Anglo-American good offices mission to France in 1958, headed up by Robert Murphy of the United states. It was a mission that has received only passing attention by most commentators on American and French affairs if they mention it at all. Why then give it any special attention here? There are several reasons that one may want to recall the Murphy-Beeley trip. As the last major diplomatic exchange with France during the Fourth Republic, it emphasizes the degree to which French-American relations had disintegrated before de Gaulle returned to public office. It indicates as well the sources of French hostility at that time. In both cases, an attempt has been made here to correct misjudgements which Americans have tended to make: the first a misjudgement which still seems to persist, that the history of Franco-American discord begins and ends with de Gaulle; the second a contention consistently put forward by government officials at the time and by Murphy in particular, that French hostility to United States policy emanated entirely from Communist quarters. Evidence to the contrary in this last case is overwhelming. While hostility was in 
evidence on the extreme Left, it was primarily individuals and parties on the kight and Right-Center who lead the opposition, and I can only conclude that Murphy and other leaders in Washington were more concerned with perpetuating a myth than with facing honestly the real reasons for French despair. France was discovering that she existed in an American world and it was not a pleasant revelation. Yet Washington would not admit to this general French concern, and it ignored, for example, de Gaulle's warning in 1958 that NATO would have to be revamped. The United States seems to have been so convinced that hostility to its policies could only be the result of Communist agitation or of personal hostility (i.e., de Gaulle) that it remained blithefully ignorant of the antipathy converging from diverse sources. Such a widespread opposition was incompatible with a conspixacy interpretation of the sources of hostility.

Thus, aspects of the 1958 good offices mission go beyond the specific event and my main concern is with these broader implications of the mission for Franco-American relations. Unfortunately, the mission reflects a poverty of American diplomacy, both in style and content, that in many ways appears typical of the Communist-obsessed postwar American foreign policy rather than an aberration. I attempt to analyze this situation in the latter part of Chapter Three and in Chapter Four. 
The second chapter, emphasizing French affairs in particular, discusses the development of Franco-American relations up to 1958. The war and the period that followed brought a shift in relations between the two countries--from one of a traditional, nodding friendship before the war to. one of real involvement afterward. One might say that relations began with the war. The French came to understand American attitudes and (probably to a lesser extent) Americans the views of the French, and it cannot be said that the two countries were as charmed with one another as they might have anticipated. The early postwar period was one of adjustment for both countries. Roles had shifted: the United States had been brought to the forefront while France had virtually been reduced to insignificance. It was from these positions that France and America began their first close peacetime association. The United States had only to learn to accept a position of world leadership, but France could not forget the role of leadership which had been hers and could not rest until that position had been regained. Conflict would unavoidably have followed a policy of the United States vis-à-vis France which assumed the new positions of France and the United States to represent the postwar status quo, which assumed American leadership and French subservience to that leadership, not for a specific period but indefinitely. And that is just the policy Washington unerringly pursued. 
CHAPTER II

FRANCE AND THE MODERN CHALLENGE

"The stalemate society" is a label that has been used by Stanley Hoffmann to describe the equilibrium of the Third Republic. Not by chance or by default was Parliament "supreme but immobile"--this was the first political system since the Revolution that had effectively adapted itself to French society, striking a balance between those who perennially stressed the need for authority and those who expressed fear of authority. "What the stalemate society needed was state protection, not domination; it wanted an instrument, not a master. . . It was a state wedded to the social status quo . . "1

Maintenance of the status quo in France's economic and international positions was a prerequisite for the survival of the stalemate society; but in the period between the two world wars, shifts in both areas brought about its disintegration. With the growth of industry and the

${ }^{1}$ Stanley Hoffmann, et al., "Paradoxes of the French Political Community," In Search of France (New York: Harper \& Row, Publishers, 1963), pp. 3, 14, 15. See also David Thoms on, Democracy in France Since 1870 (4th ed.; New York: Oxford University Press, 1964), pp. 191-92. 
problems created by the depression, dynastic and clerical issues were replaced by economic and pinancial issues. ${ }^{2}$ The Left, by taking an active part in numerous strikes, mainly over wages and working conditions, disrupted the Center coalition. Dissenters from French parliamentarism rapidly grew in strength. Anti-Republican forces on the Right which had previously tolerated the parliamentary regime "now merged their anti-Communisa into their anti-Republicanism, and began to clamour for a more authoritarian regime." ${ }^{3}$ on the Left, where more state planning and greater economic socialization was demanded, calls for a stronger government were repeated. 4

During the interwar period, one problem eclipsed all others in the area of foreign affairs, made all others trivial by comparison, and that was "the German problem." The First World War, far from solving the German problem, made it ultimately more acute.

- (T)he old balance of power, which formerly did something to restrain Germany, had broken down. Russia had withdrawn; Austria-Hungary had vanished. Only France and Italy remained, both inferior in man-power and still more in economic resources, both exhausted by the war.

2 Thomson, Democracy in France Since 1870, p. 182. ${ }^{3}$ Ibid., p. 195.

${ }^{4}$ Hoffmann, "Paradoxes of the French Political Community," pp. 30-31.

${ }^{5}$ A. J. P. Taylor, The Origins of the Second World War (2nd, ed.; Greenwich, Conn.: Fawcett Publications, Inc., 1961), pp. 28-29. 
Although greatly damaged by war and limited for the present by the Treaty of Versailles, Germany nevertheless remained the greatest power in Europe. While France looked for security, the Americans and the British, "inclined to think that they had done their work, "6 withdrew their troops from France and reduced their armies to the peacetime level. American withdrawal would have mattered less had Great Britain, France and Italy stayed in agreement. But Italy failed to contribute what little she might have, and Britain, while remaining closely associated with France, disagreed with her on the potential threat of Germany.

They (the British) tended to regerd talk of the German danger as historical romanticism, which indeed it was in the iunmediate present. The French obsession with security seemed not so much exaggerated as mistaken.?

With that analysis, British sentiment in the thirties moved back towards isolationism.

Forced in this manner to single-handedly follow a policy of keeping European peace, France assumed an undertaking she could not fulfill. Neither in spirit nor in military strength was she up to the task. The tensions created by these internal and external developments had several divisive effects on France, all of which contributed to the breakdown of the Republic and helped to prepare France for defeat in 1940.

$$
\begin{aligned}
& { }^{6} \text { Ibid., p. } 34 . \\
& 7_{\text {Ibid., p. } 38 .}
\end{aligned}
$$


First, the depression and the collapse of Versailles shook the French loose from their general complacency and prompted a widespread questioning of France's power, her claim to status and her traditional values. Both on the Left and on the Right, many became convinced that war would only destroy or further weaken a nation that had already fallen behind the stream of history, and they took refuge in pacifism. In the face of overcommitment, French public opinion, introverted from the beginning, turned defensive; the defensive posture of the Maginot Line stood as a military symbol for the wider mental outlook of all those who feared a permanent decline of the French position. Here, too, German reparation payments must be counted as a symbol. France got virtually nothing out of reparations but suspicion, moral blame, and international hostility for having ever demanded them. To this, the French reacted by losing Paith in their leaders and in themselves. "Reparations fixed the French in an attitude of sullen, but rather hopeless, resistance... (They) did almost as much damage to democracy in France as in Germany itself." 8

${ }^{8}$ Taylor, The Origins of the Second World War, pp. 4849. On the questioning of values, see Hoffmann, "Paradoxes of the French Political Community," pp. 24-26, 30-32;

H. Stuart Hughes, The Obstructed Path: French Social Thought in the Years of Desperation, 1930-1960 (New York: Harper \& Row, Publishers, 1969), 2-6, 8, 15-18. On the extent of introversionism and pacifism, see Jean-Baptiste Duroselle, "Changes in French Foreign Policy Since 1945," in In Search of France, pp. 306-18. 
Secondly, the political system fell into confusion. The National Assembly had the power to deal with the problems that arose, but

most French parties had not been created around the issue of economic and social balance or around foreign affairs, since these had been the pillars of French consensus. Consequently, when they became the major political issues, the parties proved both incapable of agreeing on coherent measures and unable to get their own members to agree. 9

Finally, lacking the spirit and the military strength to keep peace in Europe, France turned to Britain. "The main Peature of French foreign policy from 1936 onwards was its complete subservience to British policy."10 Was this a wise policy? A. J. P. Taylor argues throughout The Origins of the Second World War that Hitler had no intention of making war with the West. His argument is reinforced by an economist, Burton H. Klein, whose statistics in Germany's Economic Preparations for War demonstrate that Hitler's rearmament program did not proceed at anything like the rate that has usually been assumed or that Hitler himself claimed. Rather than planning a war with the West, they beiieve Hitler expected to extend German territory piecemeal through a series of small wars in the East. Above all, he intended to succed without provoking a great war. "The war of 1939,"

${ }^{9}$ Hof Pmann, "Paradoxes of the French Political Commnity," p. 25. See also ibid., pp. 21, 26; Thomson, Democracy in France Since 1870, PP. 182-84, 191-92.

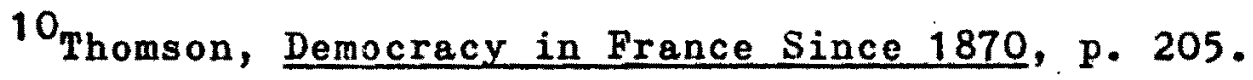


Taylor claims, "far from being premeditated, was a mistake, the result on both sides of diplomatic blunders." 11

It was Britain's revolutionary new policy of solid and indiscriminate alliance with Poland-and this commitment made without first consulting France ${ }^{12}$--that caught Hitler by surprise and left him with little choice but to advance on the West. As for France, she was dragged into war in the wake of British decisions.

The Third Republic had not wanted war, but its leaders were unable to develop a policy for maintaining peace and they were equally incapable of developing a realistic strategy of defense. The military defeat was above all a defeat in strategy; only in the number of planes did Germany hold a great material advantage over France. ${ }^{13}$ This kind of defeat Charles de Gaulle had foreseen. In his most important book on military strategy, Vers l'Armbe de Métier, published in 1934 while he was secretary-general of the National

$11_{\text {Taylor, }}$ The Origins of the Second World War, p. 212. See also ibid., pp. 210-11, 280, 284-86; Burton H. Klein, Germany's Economic Preparations for Har (Cambridge: Harvard University Press, 1959), pp. 3-27.

12 Taylor, The Origins of the Second World War, p. 205.

${ }^{13}$ Duroselle, "Changes in French Foreign Policy Since 1945," p. 323: "The number of planes at the disposal of the state in 1937 was 450 for France as opposed to 4,320 for Germany." Duroselle takes this quote from Alfred Sauvy in L'Express, April 20, 1960. See also Klein, Preparations for War, pp. 17-18, 19-20; The War Memoirs of Charles de Gaulle: The Call to Honour, 1940-1942, trans. by Jonathan Griffin, I (New York: The Viking Press, 1955), 36. 
Defense Council in Paris, de Gaulle argued that an immobile defensive strategy would not be the character of the next war. His plan called for a mechanized force of tanks and planes capable of rapid and direct attack. Although aware of de Gaulle's book, the French High Comnand did not share his viewpoint since it went in diametric opposition to the entire defensive strategy which they had planned for France. Unfortunately his book was more successful in Germany where Hitler had it read to him and insisted that all his chief advisors study it. 14

Marc Bloch, the French historian who participated in the war and wrote of the defeat soon afterward, saw the failure of French strategy as a sign of a more serious intellectual failing in leadership: "Our leaders, or those who acted for them, were incapable of thinking in terms of a new war. In other words, the German triumph was, essential$1 y$, a triumph of intellect--and that is what makes it so peculiarly serious." 15 This was de Gaulle's conclusion as well when he wrote that "the metronome of the French High Command never failed to beat several measures behind." 16

${ }^{14}$ Dorothy Shipley White, Seeds of Discord: De Gaulle, Pree France and the Allies (Syracuse: Syracuse University Press, 1964), pp. 17-33.

${ }^{15}$ Marc Bloch, Strange Defeat, trans. by Gerard Hopkins (New York: W. W. Norton \& Company, Inc., 1968), p. 36. ${ }^{16}$ Charles de Gaulle, Memoires de Guerre, I, 34-35, quoted in White, Seeds of Discord, p. 46. 
Unquestionably the war years were a divisive experience for the French. Within these divisions, were there any significant forces of unity and rejurenation to be found that had been sorely lacking even beiore the war and that would be necessary for France to adapt herself to the postwar world? This is an important but also difficult question. It is hard to contend with because, as Alexander Werth suggests, "Few things are more difficult to decipher than the minds of Frenchmen during the 1940-4 period." Mental reserrations were bound to be held in check, perspectives shifted, and moreover the period has been shrouded in myth. Resistance men magnified the role of the underground and gladly endorsed the myth that nearly all of France was résistante in 1944. Later the Right unfairly "debunked" the myth through their treatment of the French Forces of the Interior. ${ }^{17}$

The Vichy regime cannot take credit for unifying French attitudes. Rather, a trend in just the opposite direction is indicated by the course of events. In the first shock of disaster the parliamentary government of the Third Republic seemed finally discredited and the anti-Republicans of the Right won an easy victory. Marshall Pétain, whose reputation was based upon military achievements in the First

17 Alexander Werth, France, 1940-1955 (London: Robert Hale, Ltd., 1956), pp. 4, 7 . 
World War, became the last regularly appointed cabinet head of the Third Republic, and he was immediately endowed "with practically unlimited monarchical powers." ${ }^{18}$ Among the Vichy politicians, as well as among Frenchmen in general, his support was virtually unanimous in July 1940. "Almost every parliamentarian was ready to entrust France to Pétain at least for the immediate future, and many were prepared to see a permanent shift to authoritarian government." 19

Little sympathy was to be found for the system responsible for failure; even the resistance movements voiced a common critique of French parliamentarism. 20

But unity passed quickly. The French had understood at first only the need for a strong leader but soon they became more discriminating. The famous meeting between Pétain and Hitler marks the beginning of a steady decline in Vichy support and a continual rise of those who could no longer accept the Marshall's compromise. 21

Neither can Vichy claim to have maintained inner unity, to have held to a single set of objectives ris-à-vis Germany

${ }^{18}$ Ibid., 32, 39-40.

${ }^{19}$ Gordon Wright, France in Modern Times: 1760 to the Present (Chicago: Rand McNally \& Company, 1960), p. 511. See also Werth, France, 1940-1955, pp. 6, 30-32.

20 Hoffmann, "Paradoxes of the French Political Community," pp. 30-31.

${ }^{21}$ Duroselle, "Charges in French Foreign Policy Since $1945, "$ p. 326. 
during the war period. Several phases are distinguishable. Before December 1940, while Vice-Premier Pierre Lavel was in control, the keynote was defeatism and some collaboration. Between February 1941 and April 1942, under Admiral Jean Darlan's direction, Vichy worked to eliminate all remaining traces of the parliamentary Republic through the "National Revolution" program, and to turn France into Germany's closest ally. Darlan "reached--or rather, tried to reach-the peak of Franco-German collaboration." 22 After April, with the new balance created by American entry into the war, Vichy--once again under Lavel's control--retreated toward attentisme and continued in that policy until January 1944 when Nazi collaborators from Paris were forced into the Government. Thereafter Vichy represented the forces of proGermanism and opposition to it hardened. 23

The Vichy regime, rather than uniting France through the "National Revolution," divided it and drove support away. "There was a steady drift away of national opinion and feeling from defeatism and reluctant collaboration towards attentisme, and from attentisme towards resistance." 24

As a political body, the French Resistance never achieved the structural unity of Vichy. Most of the

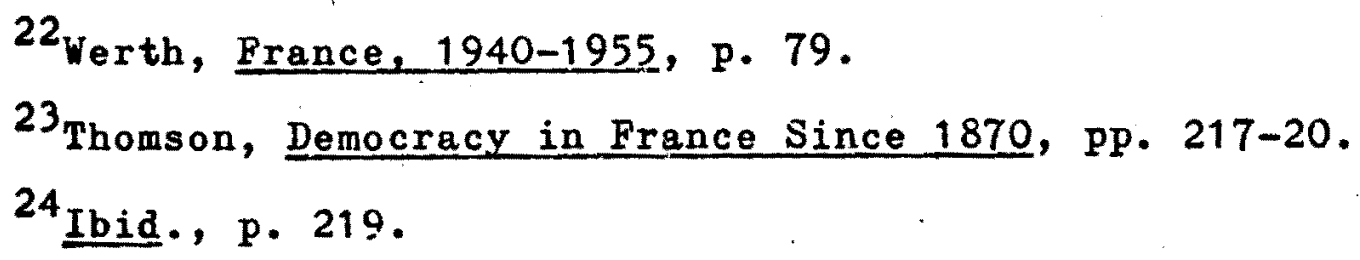


movements were originally free of politics, beginning as spontaneous resisiance to the enemy, and that is what they remained as far as the actual combatants were concerned. Leaders of the various movements, however, gradually dirtied themselves with politics. By the end of 1942 it appears that the Communist organized National Front was attempting to coordinate resistance movements under its own leadership. This they were unable to do, but Gaullist agents succeeded where Communist efforts failed when all major underground movements and political parties were welded into a nationwide federation, the National Resistance Council, on May 27, 1943. Despite the continuance of occasional friction between the underground and de Gaulle's headquarters-problems with the Communists persisted, and not all of the non-Communist Resistance was Gaullist--the Resistance remained tied to his committee after the spring of 1943.25

Although able to attain substantial unity within itself, the effectiveness of the Resistance in bringing France together during the Occupation is more difficult to measure. Opinion ranges from the comment of Duroselle that "the occupation was not a unifying force" to Henri Michel's belief

${ }^{25}$ Robert Aron, France Reborn. The History of the Liberation, trans. by Humphrey Hare (New York: Charles Scribner's Sons, 1964), pp. 70-71; Henri Michel, Histoire de la résistance (Paris: Presses Universitaires de France, 1958), pp. 41-52; Werth, France, 1940-1955, pp. 151-55, 164-69; Wright, France in Modern Times, Pp. 521-23; A. W. DePorte, De Gaulle's Foreign Policy, 1944-46 (Cambridge: Harvard University Press, 1968), p. 37 . 
that consolidation of the Resistance "spared France from a civil war in the liberation period." 26 Duroselle sees discord reflected in all the negative aspects of German occupation: the suffering, the political divisions, humiliation in defeat, the loss of freedom. But it is possible to argue that the misery in this period also led to the reestablishment of a sense of community that had all but dissipated by the end of the Third Republic. Marc Bloch wrote after the defeat, "We find ourselves to-day in this appaling situation-that the fate of France no longer depends upon the French." 27 It is significant that his statement comes in the midst of a critique on the way France handled herself when fate was in the hands of the French. There would be enough time during the Occupation for many Frenchmen to deliberate, as Bloch did, the meaning of French defeat and the direction France should take once liberty was regained. Stanley Hoffmann contends that the common suffering of the war years brought about "a kind of rediscovery of France" by the French that were able to break through the confines of the stalemate society, not in the political structure where the Fourth lepublic returned to the system of the Third, but in the economic and social spheres where "a greater awareness of the nationwide ${ }^{26}$ Duroselle, "Changes in French Foreign Policy Since 1945," p. 326; Michel, Histoire de la résistance, p. 126. 27 Bloch, Strange Defeat, p. 174. 
scope of economic problems" resulted from the programs of the main resistance movements. 28

The military value of the wartime resistance--which was not great in affecting the outcome of the war--is less important than the contribution it made toward signs of a renewed France. "There are powerful arguments for the easier road of attentisme," Gordon Wright points out. "Still, a France totally committed to attentisme in those critical years might have left a heritage quite different from that derived from the resistance mystique." 29 That French unity was so easily restored around de Gaulle's government is one of the probable differences brought about by consolidated underground support. "The recognition, sometimes implicit, sometimes overt, of General de Gaulle as head of the government was the determining condition for the prevention of disaster during those difficult days of August 1944." 30

A review of American relations with France during the war years does not reveel a pollicy that contributed to French consonance. On the contrary, it suggests that the United States either failed to understand French needs and interests or chose to give them little consideration.?

${ }^{28}$ Hoffmann, "Paradoxes of the French Political Community," pp. 39, 41 .

${ }^{29}$ Wright, France in Modern Times, p. 526.

30 Aron, France Reborn, p. 210.

${ }^{31}$ For variation in points of view, see Arthur Funk, who argues that President Roosevelt did not have designs on 
It is undoubtedly true that the defeat in 1940 caused the United States to lose faith in France. Harry Hopkins said to de Gaulle in January 1945:

The cause (of the unfortunate state of FrancoAmerican relations). . . is above all the stupefying disappointment we suffered when we saw France collapse and surrender in the disaster of 1940. Our traditional conception of her value and her energy was overthrown in an instant. . . Do not seek elsewhere for the true source of the attitude we have adopted toward your country. 32

All the same, if one does look elsewhere there is an odd incongruity to be seen in the position that President Roosevelt took toward France. On the one hand, it does not appear that he had any worked-out political plans for France, or that he was particularly concerned about what France's position would be in the postwar world. Reflecting on his conversation with Roosevelt in the summer of 1944, de Gaulle commented:

France, that his attitude toward France was not punitive (although Funk contradicts himself in this on pp. 198-99) and that there is no evidence that he wanted to keep France weak after the war, Charles de Gaulle: The Crucial Years, 1943-44 (Norman: University of Oklahoma Press, 1959), pp. 87, 300; Gaddis Smith, who insists that his desire to punish France for defeat is one of the keys to understanding Roosevelt's policy toward France, American Diplomacy During the Second World War, 1941-1945 (New York: John Wiley and Sons, Inc., 1967), pp. 12, 75-76; Gabriel Kolko, who says that "In reality it was a question of whether France should be weak or strong after the war...", The Politics of War: The World and United States Foreign Policy, 1943-1945 (New York: Random House, 1968), p. 64, passim, chap. iv.

32 The War Memoirs of Charles de Gaulle: Salvation, 1944-1946, trans. by Richard Howard, III (New York: Simon and Schuster, 1960), 92. 
The American President's remarks ultimately proved to me that, in foreign affairs, logic and sentiment do not weigh heavily in comparison with the realities of power; that what matters is what one takes and what one can hold on to; that ${ }^{\prime} \xi$ regain her place, France must count only on herself.

To the extent that Roosevelt did come to recognize the value of rebuilding France, he did not want to make it an American responsibility. That job he wanted Britain to handle. A clear example may be seen in a statement of the President's views, February 26, 1944 :

In as much as the United States is approximately 3500 miles removed from Europe, it is not its natural task to bear the postwar burden of reconstituting France: $\cdot 34$. This is properly the task of Great Britain. 34

On the other hand, by his obstinate insistence on commanding policy regarding de Gaulle and the Free French forces, it would seem that Roosevelt chose a major role for himself in directing French destiny through the end of the war and the liberation. He continually refused to recognize de Gaulle's committee and remained inflexible in this position, despite repeated British urging that recognition be granted, despite the unification of the National

Resistance Council under de Gaulle, which the United States

${ }^{33}$ The War Memoirs of Charles de Gaulle: Unity, 19421944, trans. by Richard Howard, II (New York: Simon and Schuster, 1959), p. 27.

${ }^{34}$ Department of State, Foreign Relations of the United States, Diplomatic Papers, 1944, I (Washington, United States Government Printing office, 1965), 184. 
was made aware of but never recognized and never negotiated with as a collective body, 35 and despite the fact that by January 1944 both the State and War Departments had agreed to the necessity of recognition. 36

After January 1944, Roosevelt's position became particularly indefensible. It was no longer in the interest of the United States because it had become detrimental to the war effort. Eisenhower and Stimson had argued this in January and Stimson again tried to convince the President in June. 37 Neither was his policy in the interest of France. Roosevelt's own advisors were telling him that. "Who was misinforming the President?" asks Herbert Feis. "Not the military men in France. They were reporting that the average Prenchman looked to de Gaulle 'as the natural and inevitable leader of the Free French." 38 . But all arguments were to no avail. Roosevelt refused even de facto recognition until July 1944 (more than a month after the OVERLORD invasion) and de jure recognition until October. This resistance to any recognition had become a personal policy of the President which he insisted on pursuing against all exhortation.

${ }^{35}$ Funk, Charles de Gaulle, p. 105.

${ }^{36}$ Ibid., p. 217-19, 295; Herbert Feis, Churchill, Roosevelt, Stalin, The War They Haged and the Peace They Sought (Princeton: Princeton University Press, 1967), p. 318.

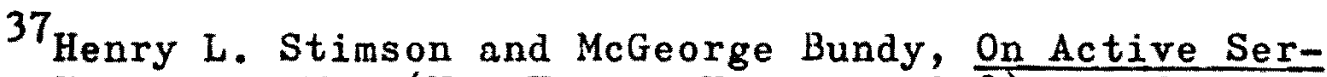
vice in Peace and War (New York: Harper, 1948), p. 551. ${ }^{38}$ Feis, Roosevelt, Churchill, Stalin, p. 321. 
By October 1944, there can be little doubt that he stood alone, among the leaders of the world, and among his advisors at home and in France, in his unwillingness to grant recognition to the French Provisional Government under de Gaulle. 39 Whatever the reason for his attitude--and a dozen fears and doubts about de Gaulle and about France have been cited by various authors--it is certain that Roosevelt did not help the cause of French unification in its most critical hour, unless he did so in a negative way by uniting Frenchmen in common indignation at the diplomacy emanating from Washington. The endless American procrastination became an almost universal French grievance in the autumn of 1944. By September, a growing number of Roosevelt's advisors were warning him of a possible revolution from the Left if he persisted in his policy. ${ }^{40}$ In January 1945, three months after recognition had been given, complaints on this issue still showed no sign of subsiding, ${ }^{41}$ and it is not unreasonable to suggest that one of the deepest roots of our postwar difficulties with France can be found in Roosevelt's dubious French policy of 1944.42

${ }^{39}$ Foreign Relations, 1944 , III, 731-48.

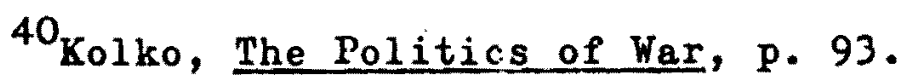
${ }^{41}$ Foreign Relations, 1945, IV, 661.

42 That is Crane Brinton's argument in The Americans and the French (Cambridge: Harvard University Press, 1968), p. 78-79. 
A peaceful transition from Vichy to the new Republic depended upon the extent to which the French would trust de Gaulle--after all, no other leader had the eminence or support necessary to ensure a quick restoration of unity. If their faith in him was unmoved by American diplomacy, it is certain that faith in their American ally was shaken.

The French defeat in 1940 was a watershed moment in the history of Europe; its significance went far beyond France: - . (I)t was the fall of France that shocked many western Europeans into the first dim realization that the Europe they had known had little chance of surviving Hitler's war. . . . (E)ren those Westerners who refused to capitulate were shaken into a new awareness. Charles de Gaulle in 1940 described the war as "the greatest revolution the world has ever known."

But even de Gaulle, who recognized the world's "greatest revolution," was unable to accept its full meaning for France. Only gradually would leaders of the Fourth Republic discover the new and painful realities of the postwar world: that there were only two great powers and France was not one of them, ${ }^{44}$ that the outcome of this war had brought an end to the epoch of European world dominance.

Although the unanimity of Gaullist support broke down soon after liberation, it foundered on domestic issues, especially on the suspicion of ulterior motives behind the

${ }^{43}$ Gordon Wright, The Ordeal of Total War, 1939-1945 (New York: Harper \& Row, Publishers, 1968), p. 234. ${ }^{44}$ Duroselle, "Changes in French Foreign Policy Since $1945, "$ p. 340. 
strong-executive form of government that he was anxious to install. Léon Blum's comment on the feeling about de Gaulle was that he "stood for democracy but did not embody it." 45 In international diplomacy, however, his views were generally accepted. Two of the most distinguished commentators on French affairs, MM. Alfred Grosser and Raymond Aron, have both pointed out that while de Gaulle's inclination to put foreign affairs above everything else disappeared with his resignation from office in 1946, his conception of France's role in the world was not abandoned. 46

The role that de Gaulle chose for France was based on the traditional idea of French grandeur. From 1944 to 1946, his primary goal was to re-establish French rank and prestige, to return France to the status of a great power. How was this to be accomplished?

I intended to assure France primacy in Western Europe by preventing the rise of a new Reich that might again threaten its safety; to co-operate with East and West and, if need be, contract the necessary alliances on one side or the other without ever accepting any kind of dependency; to transform the French Union into a Pree association in order to avoid the as yet unspecified dangers of upheaval; to persuade the states along the Rhine, the Alps, and the Pyrenees to form a political, economic,

${ }^{45}$ Quoted in Wright, France in Modern Times, p. 533. See also Thomson, Democracy in France Since 1870, p. 238.

46 Alfred Grosser, La Quatrieme Republique et sa politique extérieur (Paris: A. Colin, 1961), pp. 33-35; Raymond Aron, France, Steadfast and Changing: The Fourth to the Fifth Republic (Cambridge: Harvard University Press, 1960), p. 148 . 
and strategic bloc, to establish this organization as one of the three world powers and, should it become necessary, as the arbiter between the Soviet and Anglo-American camps. ${ }^{47}$

That his policy of greatness might no longer be a role commensurate with France's means was not one of de Gaulle's considerations. His understanding of the French and European situation after the war was limited by his preoccupation with reviving the traditional standards of French grandeur. Wanting to avoid a return to the old political France of the thirties, "so malleable and so convenient for its allies," 48 he did not turn to a program of adaptation, but to one rather which returned France to an even earlier era "of French policy in the great epochs before 1914 and in 1919. - . This was Foch's plan, taken up by Clemenceau in 1919, with improvements." 49 De Gaulle's view of the world in this first phase was based upon "past realities and present expectations," rather than upon "present realities and future expectations." 50 Thus, the foremost threat to security was still understood in terms of renewed German aggression; the possibility of France once again establishing herself as a great power did not seem pretentious,

47 The War Memoirs of Charles de Gaulle, III, 204-05. 48 Ibid. , p. 205.

${ }^{49}$ Duroselle, "Changes in French Foreign Policy Since $1945, "$ p. 335.

50 Simon Serfaty, France, De Gaulle, and Europe: The Policy of the Fourth and Fifth Republics toward the Continent (Baltimore: The Johns Hopkins Press, 1968), p. xii. 
despite her severely deterioriated condition; and, as for the colonial empire, de Gaulle remained impervious to the midcentury movement towards decolonization.

At home, the new spirit of renovation that had developed out of Vichy and the Resistance, placing economic and social reform above political aspirations, was foreign to de Gauile. Yet it was here that the new sense of community was located. Here also could be found the quest for power, rank and prestige 51 --goals held in common with de Gaulle's-but he did not recognize its significance or its value. Whereas the new mentality looked to expansion through a statedirected economy and an integrated European economy, de Gaulle could visualize the revival of grandeur only in terms of French political leadership. 52 He was not interested in economic matters, and his least imaginative decisions were made in this area. 53 Throughout most of the Fourth Republic, political leaders followed de Gaulle's example of focusing almost entirely on political concerns. Kemarkable economic recovery was achieved between 1946 and 1958, but much of it

${ }^{51}$ Hoffmann, "Paradoxes of the French Political Community," p. 53.

52 Ibid., pp. 53-54,56, 75; Duroselle, "Changes in French Foreign Policy Since 1945," pp. 337, 344; Thomson, Democracy in France Since 1870, pp. 233-35.

${ }^{53}$ DePorte, De Gaulle's Foreign Policy, p. 283; Wright, France in Modern Times, p. 532 . 
happened "regardless of the regime, or even in spite of it." 54 Only in the last years of the Republic, Alfred Grosser has said, did economic modernization "burst the tra-. ditional modes of thought and action," and shift inspiration for political thought from tradition to acceptance of "the constant transformation of the world in general and France in particular." 55

On the question of France's role in the postwar world, it can be seen, then, that while there was disagreement between Frenchmen as to the means--political or economic primacy--the end coincided: France had to regain her status. This was de Gaulle's central concern in 1945, and under the new Republic it became a national aspiration.

The primary collision of interests over the role that France would play came not from within France but from the world outside, and in particular from the United States. Anti-American sentiment ran the full length of the Fourth Republic and it revolved around France's repeated frustration in attempting to effect her goal. It is difficult to dispute the outcome of the political contest when one considers that, during the course of the regime, "the entire Gaullist policy of 1944-1946 failed..." "56 To Duroselle, this fact

${ }^{54}$ Thomson, Democracy in France Since 1870, p. 255.

${ }^{55}$ Quoted by Duroselle, "Changes in French Foreign Policy Since 1945," p. 344.

56 Duroselle, "Changes in French Foreign Policy Since $1945, "$ p. 337. 
indicates that the French policy of "return to normalcy" was unrealistic in a world so radically changed. 57 To many leaders of the Fourth Republic, however, it no doubt indicated a new adversary.

Understanding the development of Franco-American relations after the war demands an awareness of the psychological climate of the two countries. Humiliation is a word frequently used to describe the French reaction to the war experience and the frame of mind that characterized the period of 1944-1958. Duroselle emphasises the humiliation suffered first in defeat and later endured by France's "slight share in the common victory"; Crane Brinton points to humiliation as the pervasive response to Roosevelt's policy of non-recognition; Hoffmann describes the renewed French drive to regain her international prestige and power as a "battle against humiliation"; Grosser claims that the Fourth Republic made a "nationalism of humiliation."58 At a conference sponsored by the World Peace Foundation in 1956, a group of French delegates reported:

The future of Franco-American relations depends in large measure on the disappearance of the inferiority complex from which the French have suffered during

57 Ibid., pp. 335-37.

${ }^{58}$ Ibid., pp. 318-19, 325, 328, 330-32; Brinton, The Americans and the French, passim, chap. iv; Hoffmann, "Paradoxes of the French Political Community," p. 75; Alfred Grosser, "Commodités de l'Anti-Americanisme," Le Monde, November 25, 1958, quoted in Serfaty, France, De Gaulle, and Europe, p. 121 . 
the past fifteen years.... (T)he French all too often feel themselves to be somehow diminished, and they often acquire in consequence the pentality of an isolated and misunderstood person. 5

The essential difference in French and American attitudes in this period was "the dissatisfaction of the French and the satisfaction of the Americans when they think of the fate of their respective countries." 60 . Consciousness of failure was as real to the French as was American consciousness of success. 61 The two were often directly related.

From the first years after the war to the rejection of the Economic Defense Community Treaty (EDC) in August 1954, some of the most divisive issues of the western alliance were raised by divergencies in policy regarding Germany. The western powers had hoped, before 1947, to avoid the division of Germany, but increasing concern that Germany might move toward the Communist camp led them to encourage economic and political reconstruction in the western zones. American decision makers also warmed to the idea of German integration into the West, and policy aimed in this direction was begun when the Marshall Plan connected economic aid with European unity.

${ }^{59}$ Quoted by Raymond Aron in Raymond Aron and August Heckscher, Diversity of Worlds: France and the United States Look at Their Common Problems (New York: Reynal \& Company, 1957), p. 14 .

60 Raymond Axon, Diversity of Worlds, p. 11.

61 Ibid., p. 13. 
De Gaulle's objectives of dismemberment and strict control of Germany characterized the unambiguous French policy until 1947. This policy was brought to an end simply by allied refusal to accept it, and, from 1947 to 1950, France shifted with some reluctance to the western view of cooperation. Most of her efforts now went towards dragging out the process of German rebuilding. But in 1950, her position again shifted when she proposed the European Coal and Steel Community, for the first time initiating a movement toward European integration that would satisfy American interests and her own.

From the beginning of postwar policy there had been a small but active group of Frenchmen, stemning mainly from the Resistance, who favored a policy of cooperation with Germany, and after 1947 the idea of a European economic community gained in popularity. ${ }^{62}$ German rearmament was quite another question however. If to Americans it merely signified the next logical step in the build up of Germany, it required for Frenchmen "a complete and sudden reversal of their German policy." ${ }^{63}$ Robert Schuman, the French

62 This acceptance should not be exaggerated. Duroselle writes that "as late as 1953 and 1954 during the EDC debates, the fear of German will to dominate and the fear of being submerged by Germany's superior economic power were still very much alive," "Changes in French Foreign Policy Since $1945, "$ p. 348.

${ }^{63}$ Alfred Grosser, France Defeats EDC, ed. by Daniel Lerner and Raymond Aron (New York: Frederick A. Praeger, Inc., 1957), p. 57. 
Minister of Foreign Affairs, had declared on July 25, 1949: "Germany does not have a peace treaty. She has no army and should not have any. She has no armaments and will not have any."64 But in September 1950, at the American request for German rearmament, René Pléven, Schuman and Moch were forced to advance some proposal for Germany's participation in the defense of Europe. By structuring the issue of remilitarization in the framework of the European idea, a method that had worked successfully with the Schuman Plan, it was hoped that hostile members of the French government and Parliament would be appeased, and that, at the same time, a positive alternative might be given to the American suggestion of German rearmament through NATO.

There followed a great debate which preoccupied western diplomacy for the next three years. It was a debate carried on "in the true French style, passionate, theoretical, and confused."65 Confusion came primarily from the fact that the

EDC combined two quite different ideas, only accidentally related: that of the rearmament of the Federal Republic and that of a supranational 66 authority in the six-nation European community. 66

France's principal interest was in European unity while the ${ }^{64}$ Quoted in ibid., p. 56. ${ }^{65}$ Raymond Aron, France, Steadfast and Changing, p. 151.

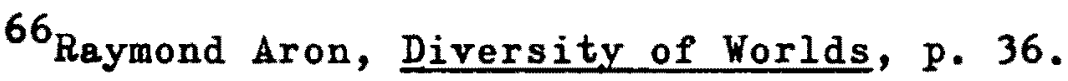


United States wanted to see Germany rearmed. But even within France, these two distinct ideas created multiple divisions .

Not only did the EDC's intended purpose become muddled, but its alternative was lost sight of as well. A substantial number of deputies in the National Assembly errored in defining the choice available to them, and voted as if the question was one of German rearmament or no German rearmament when French freedon really amounted to choosing between a French-sponsored program and the American proposal of remilitarization through NATO. Much of this confusion was vithout doubt the fault of American policymakers who, by 1954, fully supported the EDC and tried to apply pressure to obtain its ratification at a time when they should have practiced restraint. Raymond Aron states that, as to the inappropriateness of American tactics, "there was no lack of varning by Frenchmen completely devoted to the Atlantic Alliance." 67 The French mood was one of "a generally negative nationalism which, to assert its independence, rejected all projects proposed by others." 68 In this atmosphere, Mr. Dulles' clumsy declaration that an "agonizing reappraisal" would be connected with the defeat of the EDC only increased the desire of many Frenchmen to see it defeated. But their miscalculation soon became evident when,

67 Ibid., pp. 38-39.

${ }^{68}$ André Philip, France Defeats EDC, p. 26. 
four months later, these same men went through the humiliating experience of confirming the earlier American proposal.

The lesson of German rearmament for Franco-American relations was not learned very well by either country although it was repeated many times during the years of the Fourth Republic, over the Atlantic Alliance, the Suez affair and the decolonization of the French empire.

On the American side, it revealed an insensitivity to the French situation.

- . France was the only nation in which the great international problems of the period--the cold war, decolonization--became the dominant demestic issuesg the main sources of party conflicts and divisions.

This intermingling of France's foreign and domestic problems was not sufficiently understood by the United States, despite the evidence of the EDC debate. ${ }^{70}$ Had Washington given more attention to French developments and adopted a more subtle policy on the EDC, its own interest--which was to see the EDC ratified--might have been realized, and certainly much of the ensuing anti-Americanism could have been averted.

\section{${ }^{69}$ Hopfmann, "Paradoxes of the French Political} Community," p. 74. See also Charles Morazé, The French and the Republic, trans, by J.-J. Demorest (Ithaca, New York: Cornell University Press, 1958).

$70_{\text {Edgar Furniss, France, Troubled Ally: De Gaulle's }}$ Heritage and Prospects (New York: Published for the Council on Foreign Relations by Harper \& Brothers, 1960), p. 300. 
Neither was the anti-American sentiment, attached to the rejection of the EDC, a special case. What gave occasion to anti-Americanism under the Fourth Republic? "From one end to the other," Alfred Grosser has commented,

from 1947-49 until 1958, the element of antiAmericanism, springing from a feeling of dependence, seems undeniable to me. This anti-Americanism grew stronger with the impression of greater dependence on the United States.71

This "feeling of dependence" was rife by the end of the EDC debate, and much of it had been brought on unnecessarily by heavy-handed American diplomacy. Throughout Franco-American relations in the postwar period, a greater perception of French problems, a more tactful approach on the part of the United States when following its interests, would no doubt have avoided numerous strains placed on the Atlantic Alliance.

For France, the lesson of German rearmament was that her freedom to pursue traditional goals was limited by her weakness. This lesson was reaffirmed during the Suez crisis: Britain and France, the third and fourth world powers, were abruptly stopped and their interests overridden when they contradicted Soviet and American aims. ${ }^{72}$ And it was repeated throughout the long process of decolonization. But the

${ }^{71}$ Alfred Grosser, French Foreign Policy Under

De Gaulle, trans. by Lois Ames Pattison, with a Foreword by Stanley Hoffmann (Boston: Little, Brown and Company, 1967), p. 7 .

72 Duroselle, "Changes in French Foreign Policy Since 1945, " pp. 340-41. 
everpresent French desire for independence was not to be so quickly pressed into submission. In fact, humiliation and insecurity decreased after 1954 as French economy recovered. French businessmen learned that they were not inherently inferior in a competitive market, and economic ties with Germany continued to strengthen as the advantages of collaboration became evident. To the distress of American policymakers, the drive toward independence became even more exacerbated after de Gaulle's return in 1958 than it had been under the Fourth Kepublic. 
CHAPTER III

THE GOOD OFFICES MISSION OF 1958

By 1958, France's central concern was no longer Germany--it was Algeria. In the case of Germany the United States had tried to coerce France into submitting to American interests, against even the advice of American sympathizers in France, thereby creating a good deal of hard feeling for no reason. In the case of French colonialism, and the Algerian war in particular, the United States played a different kind of role. Here it pretended that it had no interests. Here it went out of its way not to interfere with French policy. But in the end the result was the same. The culmination of this policy--the seemingly innocuous (even impotent) good offices mission in the early part of 1958--was to create a new and virulent wave of antiAmericanism. A description and analysis of that mission will be the concern of this chapter while the next chapter will discuss Franco-American discord and the postwar foreign policies of France and the United States, both more generally and in greater depth, in an attempt to discover how it is that America could not seem to do right.

The war in Indochina lasted from Deceraber 1946 until July 1954, a span of nearly eight years. It ended with 
French withdrawal. Soon afterwards, in November 1954, the Algerian war began, led by what later becane the National Liberation Front, and this war outlived the Fourth Republic. "Historically," writes Raymond Aron, "the twelve years of the Fourth Republic seem to have been dominated by these two conflicts, which may be called colonial but whose magnitude made them national." 1

Algeria, even more than Indochina, inspired passionate reactions in France. However fictitious might the thinking have been which insisted "Algeria is France," this was the view taught in French schools and, even in 1958, an "overwhelming majority" of Frenchmen thought of Algeria as an integral part of France. ${ }^{2}$ The one million French citizens living in Algeria reinforced this idea and made arguments for Algerian independence more difficult. By the midfifties, Algeria had also taken on symbolic value. The regime which made a "nationalism of humiliation" saw, in Algeria, the last stronghold of French empire. Many politicians in France, particularly those on the Right, convinced themselves that the loss of Algeria would mean irreparable damage to France economically and politically. Limited to

1 Raymond Aron, France, Steadfast and Changing, p. 78.

2 Dorothy Pickles, Algeria and France: From Colonialism to Cooperation (New York: Frederick A. Praeger, 1963), p. 18; G. Barraclough, Survey of International Affairs: 1956-1958, issued under the auspices of the hoyal Institute of International Affairs (London: Oxford University Press, 1962), p. 280 . 
her hexagon, France would be forever reduced to insignificance. For the French army, whose pride had suffered most from the constant backsliding in Indochina, at Suez, Moracco and Tunisia, Algeria was also seen as the last line of resistance. Would military leaders be willing to challenge the Republic, if need be, to guarantee their position in Algeria? By 1958, military support in the political decisions of the Republic was no longer certain. French leaders-including the head of government, Félix Gaillard--were uncomfortably aware of the army's intransigence. 3

Beyond the divisions created in the search for an Algerian solution, on one point all Frenchinen agreed: Algeria was an internal French problem; a settlement formula, if one was to be forthcoming, demanded the absence of outside interference. This insistence on a French solution became, it would seem, a jealously guarded point of national honor. It became as well an increasingly difficult position to maintain. How long could a confrontation with the United States be avoided while France jeopardized NATO security by diverting most of her divisions to Algeria, or challenged the future of a European economic community with her wartime economic measures, or continued what could only be interpreted in Washington as colonialism at a time when the United States was vying for the friendship of newly

${ }^{3}$ Alexander Werth, The De Gaulle Revolution (London: Robert Hale Limited, 1960), p. 21. 
independent nations? Pressure on France grew throughout 1957 as no solution appeared. Host of the pressure was self-generated. Washington, for the most part, went out of its way to avoid straining the NATO alliance. But France understood American interests, and watched with growing suspicion for any sign that their rights in Algeria might be challenged. And if some sign appeared--e.g. the shipment of arms to Tunisia in November 1957--French politicians virtually overwhelmed themselves with hand-wringing and outbursts of indignation. 4

Hostilities grew, the army's towards the Republic which, it suspected, would soon "sell out" in Algeria as it always had before, the Left's towards the Right for not giving up in Algeria, the Kight's towards the Left for endangering chances of an Algerian "victory" by its unpatriotic attitude, and everyone's in France towards any outsider who might appear anxious to precipitate an end to the war.

The bombardment of the small Tunisian border village, Sakiet Sidi Youssef, by French forces in Algeria "once again turned the Algerian war into a question of discord within the North Atlantic alliance," 5 and finally gave some substance to the long-nurtured fears of American involvement in

4 "French Pride and Prejudice," The Economist (London), November 23, 1957, pp. 690, 692 .

${ }^{5}$ Barraclough, Survey of International Affairs: 19561958 , p. 509 . 
North Africa and "internationalization" of the Algerian conflict. The good offices mission, set up to conciliate the Franco-Tunisian rift, brought the United States and Great Britain into the North African problem to a limited degree. Defining that limit became one of the key issues in France's reaction to the mission.

Until now, the discussion of France and the United States has been general, reviewing in particular events and attitudes that shaped France's view of the world from 1944 to 1958. In this chapter, a more specific look at French-American relations will be taken through a consideration of the Anglo-American good offices mission to France and Tunisia in 1958. This particular mission concluded major diplomatic intercourse between the two countries under the Fourth Republic, and once again indicates some of the broader difficulties that persisted throughout the period.

On the morning of February 8, 1958, twenty-five French military planes strafed and bombed Sakiet Sidi Youssef in successive waves of attack for one hour and twenty minutes. It was a market day and many people had gathered in the village. According to the official Tunisian count, seventynine persons were killed, among them eleven women and twenty children; 130 persons were wounded. Most of the village was destroyed, including homes, the school and several 
International hed Cross trucks that had been scheduled to deliver relief supplies.

For France and Tunisia, the event marked the culmination of more than a year of uneasy relations. France was demanding strict Tunisian and Moroccan neutrality in the Algerian war as the price for continued friendship, but Tunisia continued to support the insurgents, to harbor rebels on her own territory and to provide them with supplies. This moral and material aid kept her position with France under constant strain. Relations had already reached a boiling point on January 11 when a French detachment was ambushed by rebel forces in Algeria near Sakiet and prisoners were reported to have been taken back into Tunisia by their captors. 6 When the Tunisian President, Habib Bourguiba, disputed this claim, refusing first to accept a French note of protest and then to receive special representatives sent by Gaillard, Ambassador Georges Gorse was recalled from Tunis and negotiations for much-needed French economic aid were dropped.

Tunisia depended on France economically, but Tunisian sympathies were decidedly with the Algerian rebels. This was Bourguiba's dilema; it restricted his flexibility in dealing with France. He could not compromise his support of the F. L. N. without damaging, perhaps irremediably, his 6 The New York Times, February 9,1958, p. 3. 
own popularity as the Tunisian leader. Bourguiba was hoping, nevertheless, to reopen discussions with France when, two days before the Sakiet incident, he suggested that Ambassador Gorse return to Tunis. 7

The bombing of Sakiet, for the first time in three years of fighting, focused worldwide attention on the troubles in North Africa, and sympathy was not on the side of France. The brutality of the attack shocked governmental leaders around the world while, in Paris, officials were stunned by the unrestrained and almost universal condemnation of the raid. 8 Le Monde predicted the worst kind of result from the bombardment for France: that internationalization of the Algerian conflict was now certain. 9

Habib Bourguiba saw the same possibility and bent his efforts toward turning Le Monde's prediction into reality. Within a week of the incident, he had submitted a formal request for a meeting of the United Nations Security Council, charging France with aggressive action at Sakiet. France filed a counter-complaint on February 14 in which Tunisia was accused of permitting the launching of rebel operations from her territory. 10 Then, on the evening of February 16 ,

\footnotetext{
7 New York Times, February 8,1958, p. 2 .

${ }^{8}$ New York Times, February 11, 1958, p. 2 .

${ }^{9}$ Le Monde, February 11,1958, p. 1.

10 United Nations, Security Council, Thirteenth Year,
} Supplement for January, February and March, 1958, Letter 
Bourguiba instructed his Ambassador to the United Nations, Mongi Slim, by telephone to prepare a new complaint to the effect that the Algerian war was threatening North African peace, thus widening his earlier complaint to include Algeria. 11

In France, M. Gaillard was caught in an embarrassing and difficult position. The order to bomb Sakiet had not been given in Paris. "Who commands in Algeria?" M. Pierre Cot asked in the National Assembly on February 11. "Civil authorities or military authorities? Then who has supreme Command" 12 When Foreign Affairs Minister Christian Pineau admitted several days later that neither he nor Gaillard nor Robert Lacoste, the Minister for Algeria, had been informed in advance of the plan to attack Sakiet, the government again came under attack. To former Premier Robert Schuman, the situation disclosed a shocking lack of government control over the armed forces in Algeria. 13

What was Gaillard to do? The Left wing of his majority, the Radicals, Socialists and Catholic Popular Republicans, were greatly disturbed over Sakiet and demanded some

dated 13 February 1958 from the Representative of Tunisia to the President of the Security Council, $S / 3952$, and Letter dated 14 February 1958 from the Representative of France to the President of the Security Council, $\mathrm{S} / 3954, \mathrm{pp} .13-16$. ${ }^{11}$ New York Times, February 17,1958, p. 1.

12 Journal officiel, Débats Parlementaires, Assemblée Nationale, February 11, 1958, p. 663.

${ }^{13}$ New York Times, February 15,1958, p. 3. 
form of appeasement. But the Right wing, Independents and Gaullists, stood in firm defense of the action. As Robert Doty described the dilemma,

- . if M. Gaillard should choose to 'cover' subordinates responsible for the order, he would be in trouble with the Center and Left. If, on the other hand, he should decide to discipline those who launched the raid, the Right would react strongly. 14 After presenting a fairly strong case against Bourguiba's belligerence, referring notably to his unwillingness to cooperate in the January incident near Sakiet, Gaillard "covered" the bombing without reservation and got a vote of confidence from the National Assembly. 15 "Afterwards it was whispered that, much as Gaillard hated doing it, he had no choice: had he disavowed the Army the effect in Algeria might have been 'incalculable'. . "16 Even if he had a choice, Gaillard no doubt hoped, by his defense of the Army, to allay suspicions that the Fourth Republic was falling into chaos.

The United States also found itself with strong interests in the Sakiet affair. Almost immediately, Secretary of State Dulles met with Hervé Alphand, the French Ambassador in Washington, to express American concern over the bombing

${ }^{14}$ Ibid., February 11,1958, p. 2.

${ }^{15}$ Voting results: 335 to 179 . Journal Officiel, Débats Parlementaires, Assemblée Nationale, February 11, 1958, p. 696.

16 Werth, The De Gaulle Revolution, p. 21. 
and to impress upon France the importance that the United States attached to the incident. of the twenty-five aircraft employed in the raid, seventeen were American-built. The incident caught the United States between its alliance with France and the image of friendship it was trying to create among new African and Asian nations. "Reactions from the Arab capitols," the New York Times stated, "showed that the Arabs regarded United States handing of the bombing as a test of the value of United States professions of sympathy for the nations that recently won their independence." 17 United States officials freely expressed hope that Tunisia could be persuaded against bringing the issue before the Security Council. Sensitive to American concerns, the Tunisian President suggested an alternative on February 13 of mediation by the United States. French leaders at first gave no indication that they were willing to modify their position, but by February 15, they had become receptive to some form of third-party conciliation. Meanwhile, anxious to head off a Security Council debate, the United States drafted a formal offer of its good offices in the dispute. ${ }^{18}$ It had probably hoped to extricate itself entirely from the dispute: on February 14, officials suggested the good offices

${ }^{17}$ New York Times, February 11, 1958, pp: 1, 4. ${ }^{18}$ Ibid., February 14, 1958, p. 1; February 15, 1958, p. 3; February 16, 1958, p. 1; February 17, 1958, p. 3. 
of Secretary General Dag Hamriarskjold, and Robert Murphy claims that the Government was "rather reluctant" to assume the task. 19

The good offices mission was set up as a joint AngloAmerican undertaking, with Deputy Under Secretary of State Robert Murphy appointed as the American representative, and Harold Beeley of the Foreign Office representing the British. If the mission did not get underway in an atmosphere of high expectation, almost everyone breathed a temporary sigh of relief at its acceptance. No party could take comfort at the thought of a Security Council debate. Neither France nor Tunisia had built a case strong enough to guarantee the outcome. The Tunisian record was marred by Bourguiba's inability or unwillingness to close the border to fellaga infiltration. France stood to lose most from an unfavorable decision in that the North African problem might become truely internationalized and taken out of French hands. And the United States, with interests on both sides, faced embarrassment whatever the result.

But the escape route offered by good offices presented an illusory solution. True, it avoided the direct confrontation that would inevitably have come from a meeting in the Security Council, but was this evasiveness altogether desirable? The good offices further confused an already

${ }^{19}$ New York Times, February 15, 1958, p. 3; Robert Murphy, Correspondence with the Author, see Appendix. 
complicated situation by its indirect method and, at the same time, sacrificed the authority needed to resolve FrancoTunisian differences.

The incompatible positions that France and Tunisia would have taken to the United Nations now became bases for defining the role of good offices. Tunisia welcomed the mission believing that, through it, the same goals it had hoped to attain in the Security Council would still be realized:

a Western commitment to an Algerian settlement; the settlement itself, based on Algerian autonomy; the evacuation of French troops froln Tunisia; an escape from the risks of extremist Moslem nationalism; and a resumption of relations, including eccnomic ties,

Although he had received no assurance from the United States that pressure would be put on France to negotiate an Algerian peace, Bourguiba interpreted a statement by Dulles, suggesting that the Algerian question could be removed from the strictly juridical status of an internal French problem, as a shift in the American position. ${ }^{21}$

Gaillard also recognized some advantages in accepting the Anglo-American mission. Support for his government came from a Parliamentary majority drawn from both the Left and the Right. Since his majority was divided on the Sakiet issue, the Left demanding appeasement and the Right insisting

$$
\begin{aligned}
& 20 \text { Furniss, France, Troubled Ally, p. } 226 . \\
& 21 \text { New York Times, February 19, 1958, p. } 3 .
\end{aligned}
$$


that no concessions be made, Gaillard could perhaps

satisfy the demands of the Left by allowing the good offices mission to do its work. Subsequent attacks by the Right could then be diverted from the Premier himself to the United States and Britain, which were already suspected by conservatives of wishing to eliminate French influence from North Africa. 22

Anxious, however, 'to minimize outside interference as far as possible, France insisted on the interpretation of "good offices" provided by international law, which limits its function to something less than mediation. 23 "Mediation" allows for suggestions by a third party in a dispute, "arbitration" for a moral judgment, but "good offices" involves no more than relaying messages between disputants until direct communication can be re-established. 24

Tunisian and French expectations of the good offices differed radically then; Bourguiba took the broadest possible interpretation and France the most narrow. American officials, perhaps bewildered by these contradictory positions, were less consistent in defining the mission's purpose. A mediating role dealing solely with the Tunisian affair, said State Department officials. But they also "saw significance in the fact that, with French consent, the United States was becoming officially involved for the first time in the

22 Furniss, France, Troubled Ally, p. 227. 23 Le Monde, February 25, 1958, pp. 1, 4. ${ }^{24}$ Furniss, France, Troubled Ally, p. 227. 
Algerian question."25

That Murphy was sent off to Europe without any clear assignment reinforced the tendency of the good offices to exacerbate confusion and distrust.. On the road to Paris, Murphy stopped in New York and London to discuss the situation with Dag Hammarskjold and Harold Beeley respectively. Arriving in Paris on February 24, he claimed only to be looking for "useful conversations." 26 While this noncommittal position accurately reflected Washington's anxiety to remain neutral, to the skeptical French opinion which met him, it suggested something more sinister--that the mission's "real" intentions were being held carefully in reserve. And suspicion increased over the next two months as Murphy traveled between Paris, Tunis and London.

In the opening talks, Gaillard emphatically told Murphy that Algeria went beyond the purview of his mission; re-establishing conditions for bilateral talks between France and Tunisia must be its single objective. 27 The good officers agreed on this point. Murphy claims in his book, Diplomat Among Warriors, that the war in Algeria "was the very last thing in which we wanted to become involved, and

$$
\begin{aligned}
& { }^{25} \text { New York Times, February 25, 1958, p. } 4 . \\
& { }^{26} \text { New York Times, February 24, 1958, p. } 4 \text {. } \\
& { }^{27} \text { Werth, The De Gaulle Revolution, p. 23; New York } \\
& \text { Times, February } 27,1958, \text { p. } 4 \text {. }
\end{aligned}
$$


we carefully avoided any implication of it in our talks." 28

But Bourguiba wanted to discuss the war when Murphy reached Tunis and, after his second meeting with Murphy, he stated that they had talked about Algeria. ${ }^{29}$ Meanwhile, the New York Times continued to speculate about a possible Algerian settlement. On March 1, the same day Murphy claimed Algeria was carefully being excluded from his talks in Tunis, the French press reported the New York Times to have said that "an American solution" was "being prepared" for the Algerian problem. 30

In retrospect, such indirect references to Algeria perhaps seen innocuous, but adament divisions in France at the time had created a mood not to be trifled with:

Not since the settlement of accounts between the wartime resistance members and collaborators, have observers here been so oppressed by an atmosphere of hatred and suspicion in public life engendered by partisanship over the issue of Algeria.

on the Right. . . ( $(t)$ he suggestion is advanced, even in high Government circles, that withdrawal from the North Atlantic Treaty Organization and from European unity would not be too high a price to pay to be left alone to "keep Algeria French."

On the Left there is enough fear of renascent domestic fascism to produce the beginning of a willingness to work with the Communists, if necessary, to bring about a peaceful settlement in Algeria and end the supressions of liberties here and in Algeria. 31

${ }^{28}$ Robert Murphy, Diplomat Among Warriors (Garden City, New York: Doubleday, 1964), p. 396.

29 Werth, The De Gaulle Revolution, p. 23.

${ }^{30}$ Quoted in ibid., p. 24.

${ }^{31}$ New York Times, March 1, 1958, p. 4. 
Neither side felt that things were going its way and each grew more insistent. Carrefour and Voici Pourquoi, the two Right-wing papers, concentrated their attacks on the good offices mission. In this climate, Murphy returned to Paris to begin his second round of talks.

M. Gaillard was having great difficulty by March convincing anybody of his government's authority. In an effort to appease his Right wing, he started a police action against the "defeatist press." On March 5, the Interior Ministry seized three Leftist periodicals, L'Express, FranceObservateur and France Nouvelle, which contained articles protesting the Algerian war. In Le Monde of March 7, M. André Chênebenoit reacted violently, objecting to circumstances in which the Right was apparently free to do whatever it wanted while the Government reserved its assaults for the Left. This tolerence only encouraged the Right's Fascist and racialist tendencies. ${ }^{32}$

Chênebenoit's warning seemed justified when, a week later, over 1000 policemen gathered outside the National Assembly, shouting expression that were anti-Parliamentary and even anti-Semitic. Supposedly an economic demonstration, the gathering was quite obviously of a political nature, and Chênebenoit again blamed the Government:

Fior months now, there seems to be an unwritten rule about political demonstrations: complete

${ }^{32}$ Le Monde, March 7, 1958, p. 1. 
indulgence towards the "super-patriots", and extreme toughness towards "defeatists". Right-wing meetings are allowed. Left-wing meetings--even the most moderate Left-wing meetings--are prohibited. No one trying to overthrow the régime is treated as a Rebel anymore; only those are treated as Rebels who show3

up the weakness of the Government and the régime. 3

The greatest weakness of the Government was that, confronted with parliamentary division, it lacked the strength to provide a needed Algerian solution. Algers frightened Gaillard, and embroilment over North Africa was pushing the French Government towards the Right as Gaillard worked not only to retain Right-wing support in France but to escape, - as well, a possible confrontation with the Army in Algeria. But efforts to gratify the kight had their limit. Gaillard was not willing to go so far as to foster a breach with the United States, and he continued to work with the good offices mission. By March 10, Murphy had won French approval for a plan to regroup and withdraw French forces from Tunisia in excess of those needed to operate the Bizerta navel base. In exchange, Tunisia would have to deny free passage and supplies to Algerian rebels by accepting neutral surveillance of its frontier and of four southern air bases at Sfax, Gafsa, Gabès and Kemade. 34

Murphy carried his newly-won proposals to Tunis only to be met with stiff resistance by Tunisia's President.

${ }^{33}$ Le Monde, March 15, 1958, p. 1 . ${ }^{34}$ New York Times, March 11, 1958, p. 10. 
Bourguiba demanded a negotiated settlement of the Algerian insurrection and added that France would have to accept, in principle, the evacuation of Bizerta. He seemed to be losing patience with the good offices mission. The good officers were given a week to choose between his and the French positions. Insisting that the mission take a clear stand, he said:

It is useless for the United States and British conciliators to come to Tunisia simply to acquaint us with Gaillard's thinking and then return to 35

But that was precisely the nature of the good office's role.

An odd occurrence followed. Tunisia radically modified its defiant position and a compromise with Murphy was reached within several days. How was this sudden shift to be interpreted? Had Bourguiba finally resigned himself to the limited function of the good offices? Perhaps the Tunisian Government realized at last that the most it could expect of the Anglo-American mission was a return to the situation before Sakiet. 36

To the French Right, Bourguiba's sharp reversal appeared explicable only if Murphy had made a secret agreement with the Tunisian leader to press for an Algerian solution. 37 A violent campaign against the good offices began in Paris in

${ }^{35}$ Quoted in New York Times, March 14, 1958, p. 6. ${ }^{36}$ New York Times, March 17, 1958, p. 9. 37 New York Times, March 19, 1958, pp. $1,9$. 
anticipation of Murphy's return. Kepresenting the Independent (moderate Right) position, Roger Duchet declared that "inadmissable concessions" demanded of France by Murphy would threaten a ministerial crisis. ${ }^{38}$

A compromise settlement was predicted in "well-informed quarters" as Murphy returned to Paris on March 17. 39 In reality, the good offices stood on the verge of collapse. Immediately in dispute, when Murphy revealed the plan he had drawn up, was a proposal that france turn over to Tunisians the four airfields in the South during the course of evacuating her 22,000 troops from Tunisia. Independents and dissident Radicals threatened to withdraw support from the Government if this point were accepted by Gaillard. 40

The larger issue, of course, was the Right's distrust of American motives. This situation did not improve after mid-March, and Gaillard's Government sank into immoblisme. On the one hand, Gaillard hoped to keep the good offices alive in order to avert further internationalization of the Algerian rebellion by bringing the Franco-Tunisian dispute before the United Nations. On the other hand, his shaky coalition government rested on Right-wing support which continued to resist the good offices mission out of conviction

$$
\begin{aligned}
& { }^{38} \text { New York Times, March } 17,1958, \text { p. } 3 . \\
& { }^{39} \text { New York Times, March 18, 1958, p. } 1 . \\
& { }^{40} \text { New York Times, March 19, 1958, p. } 1 .
\end{aligned}
$$


that its proposals favored Tunisia. Gaillard was presented with the unattractive alternative of an international or a domestic crisis. Not ready to choose immediately, he successfully stalled a Tunisian decision until the end of the month when Parliament recessed for Easter.

Before the Easter recess, Gaillard was driven by the Right to demand neutral control of both sides of the Tunisian-Algerian border as an indispensable condition for reopening direct discussions with Tunis. ${ }^{41}$ Murphy returned to London on March 10 for a five-day stay, and then carried the French demand to Tunis. In a conciliatory mood, Bourguiba agreed to a number of further concessions, but he would not accept border surveillance. This final position of the Tunisian Government was taken to France, and, because of its modifications, Murphy encouraged Gaillard to accept it.

Having assured the Assembly that border control would be the inflexible requirement, Gaillard scheduled a Ministerial Council for Friday, April 11, to discuss the latest proposal. Another sensation, however, caused him to postpone the meeting until Saturday when he received appeals from the United States and Britain urging him to keep the Tunisian dispute out of the Security Council. These messages were reinforced by a letter fron Eisenhower requesting that the

${ }^{41}$ Werth, The De Gaulle Revolution, p. 30; New York Times, April 13, 1958, sec. 4, p. 2. 
good offices be given another chance and asking the French Government not to force a choice on the United States between France and Tunisia. France, in other words, could count on the United States and Britain for no more than abstention in a Security Council vote. ${ }^{42}$

The Gaillard Government was back in the situation of three weeks before, but its room for maneuver had narrowed. Pressure from the United States was stiffer and the Independent's opposition had correspondingly increased. Gaillard's dilemma remained the same:

-. (I) $f$ he cedes to the primarily negative intransigence of the "moderates," (Independents) he can no longer count on the understanding and thus the support of our allies; if he completely takes into account the reasoning of the allies and excessively modifies the position of the French Government as hitherto defined, he risks being abandoned by $93^{\text {e }}$ of the most important parties of his majority.

Saturday's Ministerial Council, a twelve-hour ordeal, did nothing to resolve the fundamental disagreement between the head of government, who had moved toward support of the good offices' proposals, and his five Right-wing ministers. By the end of the day, an unscheduled session of Parliament had been called for Tuesday, April 15, to settle the dispute. Murphy's proposals would provide a "basis of discussion"

42"A Letter From Ike," Time, April 21, 1958, p. 19; New York Times, April 12, $195 \overline{8, \mathrm{p}} .1$.

${ }^{43}$ Le Monde, April 14, 1958, pp. 1, 3. 
with the right reserved to submit the frontier control issue to the Security Council. 44

The "moderates" believed that Gaillard was giving in to American pressure, and that they had been compensated in the frontier question after conceding the matter of air fields. ${ }^{45}$ Time magazine thanked Eisenhower for winning the Anglo-American mission a reprieve. This judgment was clearly mistaken. The letter only increased parliamentarians' hostility. True, Gaillard was probably encouraged by Eisenhower's letter to back the mission, but, to that extent, it insured his fall.

At the core of rightist irritation rested the fact that the mission had moved beyond the proper function of good offices, and in the direction anticipated. On Sunday, Jacque Soustelle, the former Governor General of Algeria who would lead the Assembly fight against Murphy's proposals, declared bitterly: "As was expected, the pretended good offices has transformed itself into a partial mediation hostile to the vital interests of France." 46 The Right was furious with Gaillard for his willingness to accept the "suicidal" recommendations which were as follows:

- EVacuation: All French troops stationed outside the Bizerta perimeter are to be evacuated in

${ }^{44}$ Werth, The De Gaulle levolution, p. 31. ${ }^{45}$ Le Monde, April 15, 1958, p. 1. ${ }^{46}$ Quoted in New York Times, April 14, 1958, p. 4. 
accordance with a time-table to be agreed upon by France and Tunisia.

BIZERTA: While not contesting Tunisia's sovereignty over Bizerta, France shall negotiate with Tunisia a new status of Bizerta before the regrouping of the French troops now in Tunisia.

AIRFIELDS: Neutral observers shall be stationed at the four airfields in South Tunisia--Sfax, Gafsa, Gabès and Remade--to see to it that these are used only for peaceful purposes.

CONSULATES: Certain French consulates in Tunisia which were closed in February may now be reopened. EXPELLED FRENCH CITIZENS: The Tunisian Government will reconsider individually the case of all the 600 French citizens "removed" from their residences in Tunisia, and will decide whether it is safe for them to return. 47

It is perhaps of little importance to discuss the essential moderation of these proposals, or, as Nurphy himself does, to point out that de Gaulie's later agreement with Tunisia was less favorable to France than his own proposals in analyzing the anti-Americanism that dominated the Assembly on April 15. The hostility of the Right, as Le Monde immediately suggested, was less the result of the good offices than the conviction that the mission worked against the Government. ${ }^{48}$ The execution of the good offices and of Gaillard's Government had been decided in advance of the Assembly meeting.

On April 15, both came under attack. Pierre André of the Independent party directed his fire at the Government. France's position in the Sakiet affair had been "perfectly

47 Quoted in Werth, The De Gaulle Revolution, p. 31. ${ }^{48}$ Le Monde, April 17, 1958, pp. 1, 2. 
defensible." ". . . (I)f you (Gaillard) had fully accepted your great responsibility, you never would have accepted what the good offices proposed to you." 49

Throughout the debate, it was suggested that Gaillard's support of the Murphy Plan resulted from foreign pressure. At one point when Gaillard denied this, a member of the Right interjected: "Come on, you'd better read Ike's letter to us!" Soustelle's attack was more direct:

M. Soustelle: After the failure of the "good offices", the only thing that would explain the Government's present policy is Eisenhower's letter. (Loud cheers on extreme Right and on numerous kight and Center benches.)

M. Gaillard: That's penny novelette stuff!

M. Soustelle: So you say you haven't yielded to outside pressure?

M. Gaillard: I have not, and I repeat it.

M. Soustelle: The fact is that you've obeyed a summons, and this will happen again. Where, I ask you, is Frepgh policy decided--in Paris or in Washington? ${ }^{50}$

Towards Murphy and the good offices mission, Soustelle

was equally severe:

The good offices were only justified if they dealt with the question of Tunisian neutrality. But from the beginning the partiality of MM. Murphy and

Beeley toward Bourguiba's Tunisia was evident. The good offices were rapidly transformed into mediation, and then, it must be said, into arbitration exercised againstus. The problem of belligerence was

${ }^{49}$ Journal Officiel, Débats Parliamentaires, Assemblée Nationale, April 15, 1958, pp. 2140-41.

50 Quoted in Werth, The De Gaulle Revolution, p. 34. Some passages here have been condensed. For full exchange see Journal Officiel, Débats Parliamentaires, Assemblée Nationale, April 15, 1958, pp. 2145-46. 
completely left aside. If $M$. Murphy had exercised on $M$. Bourguiba a hundredth of the pressure he put on the French government, $M$. Bourguiba would have been obliged to renounce his belligerence against France. Very good! Very good! from several benches of the center, the right, and the extreme right.)

The good offices mission, he argued, was the first step toward abandoning Algeria. Could anyone doubt Algeria's importance?

Remember the lessons of the Third Republic. It tolerated the loss of the khineland, then the Anschluss, then Munich. And this ended with the destructign of the regime and the defeat of the country. 52

It was now American diplomacy that threatened the repetition of these lessons. Soustelle exploited the theme of antiAmericanism thoroughly and decisively before the debate had ended and the good offices' recommendations had been rejected. By extending good offices, the United States had hoped to avoid straining its friendships with France and Tunisia. This it had failed to do. Worse still, no conclusion was brought to the French-Tunisian conflict. "The Americans have sown money and gathered abuse, without securing any progress towards a solution," The Economist reported. 53

Instead, a crisis had been precipitated in the French regime. The coalition that defeated Gaillard--the Right and the

51 Journal Officiel, Débats Parliamentaires, Assemblée Nationale, April 15, 1958, p. 2145.

52 Ibid., p. 2147.

53"France's Misdirected Fury," The Economist, April 19, 1958, p. 187 . 
Communists--would not work together to form a new government, and it was not certain from what quarter a new government would appear. "You are going to open up a crisis. How long will it last?" Gaillard asked the Assembly moments before his government was overthrown. It lasted longer than any cabinet crisis of the Fourth Republic. In fact, the regime never recovered.

Hardly anyone could have been shocked at the failure of the good offices mission; from the outset observers had predicted a less than even chance of its success. Americans were suprised, however, by the tremendous hostility unleashed towards the United States during the Assembly debate over the good offices' proposals. 54

It should be remembered foremost, in judging the French reaction to the good offices, that, rightly or wrongly, the United States did not represent a neutral conciliator to the French. There is no single historical moment of antagonism to which one may turn in order to locate the source of French animosity and distrust. The war experience, i.e., American treatment of de Gaulle, had not been forgotten by the deputies in Parliament. Indochina presented a more recent source of suspicion. André Morice, who stood ideologically next to Soustelle in the debate of April 15, says:

${ }^{54}{ }_{\text {New York Times, }}$ April 17, 1958, p. 3. 
The French, and I was among them, took badly the interference of the United States in an affair (Sakiet) considered at the time as a French affair. Let us not forget that this came after a clumsy United States policy in Indo-China where, instead of helping the French, the Americans did their best to complicate every problem. . . 55

That was the Right's impression of Indochina; the United States, by its lack of cooperation, was held partly responsible for French defeats there. Closer still to the Sakiet incident was the Suez affair, another French raneuver favored strongly by the Right. Had American pressure to abandon the expedition been withheld, "not only the Nasser problem would have been settled, but also the problem of French Algeria." 56

These events provided a general background for shaping the attitude of the French Right toward the United States. The sensitive North African issues furnished a more specific and immediate framework. Soustelle claims that the irritation he felt towards the "so-called" good offices mission arose, above all, from "the incomprehension of our allies in the Algerian affair." 57

Several occurrences in 1957 indicated to the French that a definite view on Algeria was evolving in Washington. In July, John Kennedy made a long and pointed speech before Appendix.

${ }^{55}$ André Morice, Correspondence with the Author, see ${ }^{56}$ Ibid.

57 Jacque Soustelle, Correspondence with the Author, see Appendix. 
the Senate, highly critical of France's Algerian policy:

The war in Algeria, engaging more than 400,000 French soldiers, has stripped the continental forces of NATO to the bone. It has dimmed Western hopes for a European common market, and seriously compromised the liberalization reforms of OEEC, by causing France to impose new import restrictions under a wartime economy. 58

He also challenged American reluctance to consider the Algerian problem in any terms other than as an exclusively French concern:

The war in Algeria confronts the United States with the most critical diplomatic impasse since the crisis in Indochina--and yet we have not only failed to meet the problem forthrightly and effectively, we have refused to even recognize that it is our problem. . . .59

Kennedy's speech made an impression among policymakers both in Washington and in Paris. The sympathy he showed for the cause of Algerian independence was understood by many in France to represent the opinion of American officials less free to express themselves.

In November, M. Bourguiba appealed to the United States for arms after his request had been ignored by the French Defense Ministry. When the United States and Britain responded by rushing several thousand rifles and machine guns to Tunisia, the French interpretation of Kennedy's speech seemed to have been confirmed. In France, the reaction was violent

58 Congressional Record, 85 th Cong., 1st sess., vol. 103, pt. 8 (July 2, 1957), 10781.

${ }^{59}$ Ibid., p. 10780. 
and indignant--the press unanimously condemned the AngloAmerican arms shipment while representatives of every political position repeated the question, Had France become less important than Tunisia? France's own policy toward Tunisia, which hoped by restraining Tunisia to favorably influence the Algerian struggle, had been punctured publicly by the action of her allies. The conclusion drawn by France from the incident was more than just a hypersensitive French reaction, for The Economist saw the same meaning in the arms shipment: a warning that Washington would not put up with France's North African policy much longer. 60

Iet the incident was apparently not meant to be a warning at all. It resulted instead from a decision based on several mistaken assumptions: that if Bourguiba did not get arms from the West he would turn for help to the Soviet Union, and that the weapons would be used only to protect Tunisia against the infiltration of Algerian fellaga! 61 With a curious lack of perception, the American and British Governments had failed to anticipate the effect their nove would have on France. Probably it was the hint of Communist arms that had caused Washington to react without consideration for its ally.

60"French Pride and Prejudice," The Economist, November 23, 1957, pp. 690, 692.

${ }^{61}$ Curtis Cate, "Ambassador Murphy's 'Good Offices,'" The New Republic, April 21, 1958, pp. 5-6. 
The Tunisian arms shipment had been a blunder, not a warning. Kennedy came much nearer the truth than did The Economist when he suggested that the United States was not at all prepared to face up to the North African problem. American behavior at the December NATO conference in Paris made this clear enough. Since all but two of France's fourteen divisions had been diverted from Europe to Algeria, one might have expected discussion of this disruptive phenomenon at a conference called for the announced purpose of recementing the shaken NATO alliance. Instead, the United States agreed to leave North Africa out of the deliberations. 62 The "French Algerians" saw enough evidence in Kennedy's speech and in the shipment of arms to Tunisia to confirm suspicions that America would soon be applying pressure for an Algerian settlement. It was whispered in Paris during the NATO conference that the imperialistic Americans were after Algerian oil. Contrary to this impression, the arms shipment and the NATO conference indicate the position Washington would actually take regarding the Sakiet bombing, and they point at the same time to one of the gravest problems of American foreign policy of the period. The United States was attempting to pursue a middle way between diplomacy and

62 Ibid.; Curtis Cate, "NATO and North Africa," The New Republic, May 5, 1958, pp. 7-9. In Raymond Aron's opinion, the United States lacked leadership; see R. C. Doty, "As NATO Meets: What Europe Says of Us," The New York Times Magazine, December 15, 1957, pp. 61-62. 
force: Fundamentally, it was trying to avoid policy. This above all was "the reason for the preordained barrenness of Mr. Murphy's mission," Curtis Cate wrote in The New Republic. He added:

When anything goes wrong in the world, the Administration is tempted to believe that things can be set right be sending out a good will ambassador who will charm the conflicting parties back into benevolence and concord. . . This attitude--it cannot be called a policy--deserves to be called the Dale Carnegie approach to power politics. . . . His (Murphy's) mission has perhaps been the purest example we have yet been offered of ${ }_{6}$ public relations as a substitute for foreign policy. 63

Considering the good offices mission as a public relations venture, some attention must be given to the image of the American representative, Robert Murphy. Christian Pineau, in deeming his appointment to have been "insensitive," 64 presents a rather widely accepted view that denands some exposition.

The reputation that Murphy had earned from his wartime activities was particularly unsuited to appease Gaullist circles in 1958:

They attributed to him an attitude hostile to the General's person, from the fact that he was President Roosevelt's representative and that his personal activity had beg neemed, in 1944, favorable to General Giraud. 65

${ }^{63}$ Cate, "Ambassador Murphy's 'Good Offices," p. 6. ${ }^{64}$ Christian Pineau, Correspondence with the Author, see Appendix.

${ }^{65}$ Ibid. 
De Gaulle himself placed Murphy high on his long list of adversaries and despised him to the point of hatred. When Murphy requested a meeting with de Gaulle, after coming to Paris, he was coldly refused. 66 Determining the attitude of the Right toward his appointment required little speculation on Murphy's part. Immediately upon arriving in Paris in February, he read an article by Michel Debré, one of the representatives of Gaullist opinion, which suggested in effect that he return home inmediately. 67 As Schoenbrun puts it: "The Gaullists howled with rage, and a wave of anti-Americanism swept over France:" 68

The indiscretion of Murphy's appointment was a reflection of Washington's failure to consider the importance of rightist animosity. ". . One may say that between 1947 and 1957 anti-Americanism in France passed from the Left to the Right," Alfred Grosser has written. ${ }^{69}$ This shift was brought about chiefly by American failure to support the Right's two favorite prograns: the Suez policy and Algerian "pacification." But the United States remained oblivious to

${ }^{66}$ David Schoenbrun, The Three Lives of Charles de Gaulle (New York: Atheneum, 1966), pp. 125, 231.

67 Murphy, Diplomat Among Warriors, pp. 395-96; Murphy, Correspondence with the Author, see Appendix. p. 231 .

${ }^{68}$ Schoenbrun, The Three Lives of Charles de Gaulle,

${ }^{69}$ Quoted in Furniss, France, Troubled Ally, p. 301. 
the emerging hostility frorn the Right, and continued to interpret all anti-Anericanism by the standard formula-Communist agitation.

The Communists did, of course, adopt their familiar anti-Government, anti-American line during the debate of April 15, and they voted solidly against the Murphy-Beeley recommendations. But the most vehement attacks came from the Right. Moreover, since the success of Gaillard's coalition government depended upon the support of the Right, not of the Communists, their vote was unimportant. A vote of affirmation was never expected from that quarter. These facts should have been blatently obvious, especially to Murphy because of his closeness to the events. Yet, in several addresses given by him after returning from Europe-on May 19 before the Senate Foreign Relations Committee and on July 1 at the 1958 Colgate Foreign Policy Conference in New York--he blamed Soviet propaganda for exciting the antiAmerican sentiments in France. ${ }^{70}$

In one sense, Murphy's war credentials were well suited for the good offices mission of 1958. During the war he had restricted himself to the role of reporting conditions in Algeria. He shunned policymaking. ${ }^{71}$ Obscurity, derived

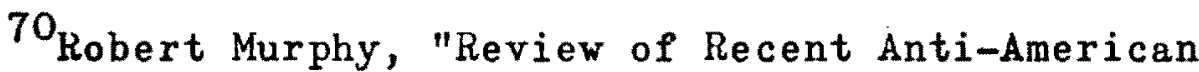
Demonstrations," The Department of State Bulletin, XXXVIII (June 9, 1958), 952-61; Robert Murphy, "Basic Elements in United States Foreign Policy," The Department of State Bulletin, XXXIX (July 28, 1958), 141-46.

${ }^{71}$ Funk, Charles de Gaulle, pp. 90-91. 
from avoidance of policy, characterized his war image.

Robert Aron has called him "that most enignatic of diplomatists." "Indeed," says Aron,

he was so enigmatic that he gave every appearance of puzzling himself. This curious man often gave the impression of not understanding the issues involved; perhaps this very fact enhanced his reputation. He was everybody's friend. Right wing with the Right, Left wing with the Left, he reflected all the prejudices and errors of American. diplomacy. Indeed, 42 not only reflected them, he exaggerated thom. 72

Aron, referring here to the war period, might easily have been speaking of 1958. Murphy again represented the Administration's approach par excellence.

In his book, The De Gaulle Revolution, Alexander Werth tends to equate the unpopularity of the good offices with the unpopularity of Robert Murphy, stressing the extreme distrust that Murphy's image delineated. ${ }^{73}$ But this is to place too much blame on the American Ambassador. After all, he was, as has just been stated, an admirable representative of Washington's position.

Many Frenchmen involved in the events of the good offices mission concur in the opinion that, while Murphy's appointment was imprudent, he does not deserve to carry all the responsibility for the French reaction but might best be seen as an additional factor of antagonism. Although Pineau, for example, considers Murphy's choice to have been an

72 Hobert Aron, France Reborn, p. 216.

${ }^{73}$ Werth, The De Gaulle Revolution, pp. 22-24, 30. 
insensitive one, the fact remains that "any other choice would have also brought reservations with it," for the good offices mission itself "seemed to (the Gaullists) an attack on French sovereignty in the form of an Anglo-American intrusion in an affair considered a purely national matter." 74 This impression is confirmed by André Morice, Léon Delbecque, Pierre Pflimlin and André Philip, as well as by Alfrẹ Grosser and Raymond aron. ${ }^{75}$ Exactly how decisive a role he played in the failure of the good offices mission--and thus the fall of the Gaillard Government and even the downfall of the Fourth Republic--is a matter more open to disagreement. Opinion varies from Grosser's conclusion that his role was indeed decisive to Aron's judgement that it was, in the end, of little importance. ${ }^{76}$ Perhaps all these men could agree with Schoenbrun's dictum:

In the greater scheme of things Murphy was only a small pebble among the many boulders on the rocky road of French-American relations. But it was the kind of small pebble which gets inside a man's shoe and causes a pain and a stumbling out of all proportion to its size and importance. 77

${ }^{74}$ Pineau, Correspondence with the Author, see Appendix.

${ }^{75}$ André Morice, Léon Delbecque, Pierre Pflimlin, André Philip, Alfred Grosser, Raymond Aron, Correspondence with the Author, see Appendix.

${ }^{76}$ Grosser and Raymond Aron, Correspondence with the Author, see Appendix.

p. 125 .

77 Schoenbrun, The Three Lives of Charles de Gaulle, 
It may seem suprising that some of those, whose attacks on Murphy were the most clamorous in 1958, go the farthest today in releasing him from censure. Who would expect to hear Soustelle say that "The personage of $\mathrm{Mr}$. Murphy was not concerned" in "the attitude of a great many members of Parliament and of myself towards the so-called 'good offices' mission..." ${ }^{78}$ And André Morice, who shared Soustelle's opinions in 1958 now writes:

If Mr. Murphy's good offices mission became a stalemate, this is not due, according to my thinking, to Mr. Murphy's personality, a personality which we have no need to discuss. If anyone other than Mr. Murphy had been placed at the head of this delegation, he would have done no better.79

These statements indicate a rather remarkably congenial attitude toward Murphy when compared with the views being expressed by the same men in April, 1958, and they would appear. to indicate once again that the denouncements of Murphy cannot be taken too literally. The issues of animosity were larger than one man's personality.

No American representative would have been very well received. Perhaps Ministers and members of Parliament remembered Murphy's past, but most Frenchmen had forgotten it. Yet, public opinion was no less skeptical of the good offices mission than the French Government. "It is thus not Mr.

${ }^{78}$ Soustelle, Correspondence with the Author, see Appendix.

${ }^{79}$ Morice, Correspondence with the Author, see Appendix. 
Murphy's presence at the head of the good offices mission, which explains the mistrust of a part of public opinion and the hostility of another part towards this mission." 80 The source of hostility was to be found in the French interpretation of the mission "as an underhanded attempt (by the United States) to internationalize the Algerian conflict." 81 The concern here is not with the truth or falseness of the French view, but with an American style and an American representative that encouraged distrust needlessly be their approach to diplomacy. To prove that French suspicions were groundless (as they probably were) does not vindicate the United States. The Administration, anxious to play a dual role in the Franco-Tunisian conflict of holding the NATO alliance together on the one hand and sympathizing with Arab nationalism on the other, tried to walk on neutral ground where there was none. While Kennedy's speech was at least useful to the French in exposing an American position that could be appraised openly, the Administration's noncommittal attitude only complicated an already equivocal situation. Probably no other diplomatic approach by the United States was better suited to aggravate the suspicions and xenophobia already present in France. At the same time, it accomplished nothing. In positive results, the good offices Appendix.

${ }^{80}$ Delbecque, Correspondence with the Author, see 81 Ibid. 
mission was barren, maturing a crisis without precipitating solutions. The Franco-Tunisian dispute continued. The war in Algeria was no nearer a solution. No stand had finally been taken by the American Government towards Algeria, a problem vital to its own interests--indeed, the whole purpose of the good offices mission had been to avoid that kind of decision. American "meddling" had only confused and infuriated Frenchmen unnecessarily. At every level of consideration, the good offices mission of 1958 can be understood as an indication of Washington's unpreparedness to define a policy towards North Africa or to face up to the true complexity of the political situation in France. 


\section{CHAPTER IV}

DE GAULLE RETURNS

After the establishment of the Fifth Republic, there was a tendency among Americans to lose sight of the fact that Frenco-American discord had predated the new regime and to blame de Gaulle entirely for foreign policy divergences. "Because they tended to judge other nations in terms of individual personalities rather than their historic interests," Walter LaFeber comments, "Americans tended to believe that Franco-American agreement would be fully restored whenever de Gaulle departed from the scene." 1

It was not exclusively an American reaction to turn to the figure of General de Gaulle when searching for the source of further disparity in the French and American positions. Duroselle wrote in 1964: "It is beyond doubt that the role of the General in the creation of this (Franco-American) tension is of major importance, if not totally responsible. ${ }^{2}$

${ }^{1}$ Walter LaFeber, America, Russia, and the Cold War, 1945-1966 (New York: John Wiley and Sons, Inc., 1967), p. 237 .

2Jean-Baptiste Duroselle, "De Gaulle's Designs for Europe and the West," Changing East-West Relations and the Unity of the West: Papers Presented to the EuropeanAmerican Colloquium, May 1 and 2, 1964, at the Washington 
Yet there was more than a modicum of truth (and warning) to be found in Jean Cau's observation that "De Gaulle does not exist. He is just the idea the French have about themselves." ${ }^{3}$ After years of discord, de Gaulle did not forge domestic concensus solely on the basis of his personal prestige and without regard for French interests-as too many Americans imagined. Stanley Hoffmann deems it a "basic, obvious fact: the personal style of the General gives its special shape to a policy which, in its aspirations and connotations, corresponds to French desires." 4 Even Duroselle did not suggest that agreement would be restored after de Gaulle's rule had ended. Duroselle distinguished between de Gaulle's tactics and his overall strategy, or long-range views. Were it only Gaullist tactics that provided the source of friction, conflict could pass with de Gaulle. But the long-range goals which made up de Gaulle's program and which had the support of the French also conflicted violently with the Atlantic policy of the United States. 5

Center of Foreign Policy Research, School of Advanced International Studies, The Johns Hopkins University, ed. by Arnold Wolfers (Baltimore: Johns Hopkins Press, 1964), p. 177 .

${ }^{3}$ Quoted by Henri de Turenne, "Grand Subject," The New Iork Times Magazine, September 12, 1965, p.'114.

${ }^{4}$ Stanley Hoffmann in the Foreword to Alfred Grosser, French Foreign Policy Under de Gaulle, p. xi.

${ }^{5}$ Duroselle, "De Gaulle's Designs for Europe and the West, " p. 197. 
French dissatisfaction with the Atlantic Alliance did not begin with de Gaulle's return. Alfred Grosser suggests two elements which made Atlantic solidarity a "reluctant choice" for the French under the Fourth Republic. The first, mentioned above, was "the element of anti-Americanism springing from a feeling of dependence..." The problems of decolonization--the loss of Indochina and the Algerian war-heightened the sense of dependence for they were accompanied by a feeling that France was declining while the United.

States was rising.

The second element of malaise involved in the Atlantic choice was based on the impression that the United States would not guarantee French security when certain actions, rightly or wrongly deemed essential to French security, ran counter to American policy--such as the Suez expedition in 1956 and even the Algerian war. 6

Thus, as the feeling of dependence increased, the impression that French interests would be protected by this dependence decreased.

This analysis is useful in interpreting the response of distrust and anti-Americanism to the 1958 good offices mission. Specific incidents, such as Eisenhower's letter, as well as the mission in general, stimulated both elements of malaise. The feeling of dependence was blatantly demonstrated by Soustelle's performance in the Assembly, and particularly with his question, "Where, I ask you, is French 6 Grosser, French Foreign Policy Under de Gaulle, p. 7. 
policy decided--in Paris or in Washington?" Simultaneously, the tenor of the letter and the very fact of the mission suggested that French interests would not be guaranteed by the United States.

It is not suprising, then, that criticism of American diplomacy in the Franco-Tunisian dispute continually went beyond the specific issue of the good offices mission--the larger concern was with the Atlantic Alliance system. When Soustelle complained of American willingness "to sacrifice its European allies in its ridiculous search for Arab friends, lest they fall under Communist influence," 7 he was calling into question the validity of American foreign policy in general as it related to French interests.

What were the aims of American policy? Since the Second World War, the United States has relentlessly pursued two goals in its foreign policy: the first is antiCommunism; the second is the defense of peace. In the second chapter, I emphasized primarily the clumsimess of of American attempts to impress its interests on France and, in the third chapter, the essential shallowness of American foreign policy. These two points are related by their interconnection with American goals--in particular, by the enormous American concern with Communism.

\footnotetext{
${ }^{7}$ Quoted in Alexander Werth, De Gaulle: A Political Biography (Baltimore: Penguin Books, Inc., 1967), p. 12.
} 
The United States, unlike its allies, made antiCommunism the guiding principle of its foreign policy. What sort of a program could be constructed on the principle of anti-Communism? Duroselle claims that the United States did not develop an ideology after the war; rather it built a counter-ideology in reaction to Communism. ${ }^{8}$ Whatever label is applied, the results of the American policy of reaction have been several.

The first can be seen in the poverty of American foreign policy. I have described the good offices mission as an anti-policy effort. As such, it was more representative than unique, for when Washington was not confronted with a clearcut case of Communism versus anti-Comrnunism it found itself in the uneasy position of not knowing what its interests were, or if it had any special interests. Only when reacting to or anticipating what it viewed as a Communist advance did Washington move with self-assurance. And the overbearing enthuasism shown by the United States when attempting to secure itself from Communism often offended and antagonized France by its tactlessness and narrow vision, by the lack of concern shown for alternatives which might have incorporated the additional interests of of its ally. Such was the case of the EDC debate in 1954.

${ }^{8}$ Duroselle, "De Gaulle's Designs for Europe and the West," p. 182 . 
An anti-Communist counter-ideology, if nothing else, has proven to be too narrow a base for the construction of an entire foreign policy. The real complexity of foreign affairs, brought about by the separate national interests of the United States and its allies, defies reduction to such a restrictive framework. In an article entitled "The Impotence of American Power," Hans Morgenthau wrote in 1963: - . (0)ur impotence is aggravated and rendered irreparable by our commitment to anti-Communism as the overriding objective of our foreign policy. For most of our allies, anti-Communism is at best incidental to concrete national objectives and at worst irrelevant to them...9

What is more, anti-Communist policy insists on the primacy of its goals at all times.

Conflicting analyses of the Communist danger underlay much of the disparity in French and American foreign policy aims after the mid-fifties. The extension ad absurdum of the United States commitment to anti-Communism can be seen as a second adverse result of its counter-ideology. For a time, especially during the period of Stalin's provocations, Communism appeared as a menace to the national interests of all Western powers. The threat diminished by the mid-fifties however, and as one might expect, national priorities in France shifted; but not in the United States where a program of anti-Communism had become the key to maintaining peace in the world. The United States clung to Manichean

${ }^{9}$ Commentary, November, 1963, pp. 384-86. 
interpretations of the cold war, like those of President Truman or John Foster Dulles; its view of the world remained limited to the contest of forces of good and evil as it battled the Communist ogre. 10

In France, this view lost its vitality by 1955. The French public became less concerned with Communism than with protecting French indepondence from the United States. One public opinion survey reveals that while until October 1954 approximately the same number of Frenchmen wanted France to remain committed to the West as those who wanted her to be uncommitted, by June 1955 Frenchmen chose to side with neither the East nor the West in a ratio of three to one over those who preferred commitment to the West. This ratio seldom fell below two to one during the remainder of the Fourth Republic. ${ }^{11}$

As the Soviet menace subsided, it was the American presence, not the Russian, that confronted Europeans. The concern generated by this revelation was already evident during the Fourth Republic, but by the sixties it had virtually turned into Americanophobia. Etiemble's best-seller, Parle-vous franglais?, owed its extraordinary success to

10 Duroselle, "De Gaulle's Designs for Europe and the West," p. 182 .

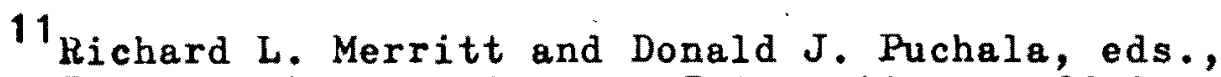
Western European Perspectives on International Affairs: Public Opinion Studies and Evaluations (New York: Frederick A. Praeger, Publishers, 1968), p. 220. 
the virulent anti-Americanism that it represented. ${ }^{12}$ AntiAmericanism was a reality of the Fourth Republic; the Fifth Republic made it into a virtue. W. W. Kulski points out in his book on de Gaulle that French patriotism "today is colored by anti-Americanism as for many past decades it was colored by a strong Germanophobia." ${ }^{13}$ The intensity of Americanophobia was well expressed by Maurice Duverger in an interview in 1964:

It must be said, it must be written--the sole near danger for Europe is American civilization. There will be neither Stalinism nor communism in France. All that is a scarecrow that no longer frightens anyone but the sparrows. From 1946-48, in 1952, there was still a communist danger, but today all that appears past. In contrast, the pressure of American society, the domination of the American economy, the invasion of the American mentality-all that is very dangerous. 14

American domination directly contradicts the central foreign policy objective which France has sought to realize under both the Fourth and the Fifth Republics: the resumption of a status worthy of her historic mission. The basic foreign policy objectives of the United States and France

12 Grosser, French Foreign Policy Under de Gaulle, p. 140; see also John Ardagh, The New French Hevolution, Harper Colophon Books (New York: Harper \& kow, Publishers, 1969) pp. 264,458 .

${ }^{13}$ W. W. Kulski, De Gaulle and the World: The Foreign Policy of the Fifth French Republic (Syracuse: Syracuse University Press, 1966), p. 77.

${ }^{14}$ Georges Suffert, "Entretien: Maurice Duverger," L'Express, March 5, 1964 , pp. 39-40. 
not only differed in the fifties and sixties but conflicted-both countries chose leadership roles. And the philosophical bases on which their respective objectives were justified disagreed as well.

The French desire since the war to recover its rank has never been a goal supported by the United States. In the forties and fifties it seemed a romantic impossibility; in the sixties, when it was possible, it vas denounced as anachronistic. The reason is clear. With its attention riveted to what it perceived to be the creeping danger of Communism, the United States judged the continuance of its presence in Europe to be mandetory for the duration of the East-West confict. This presence has not, of course, been seen by the United States as a matter of domination, but rather as a matter of protection under American leadership. But it demanded the support and, it must be said, the submission of France to this leadership. General de Gaulle, who chose to reaffirm French independence whenever possible instead of looking to American guidance, was frequently the subject of vehement American criticism, his actions deemed tantamount to treason. Now, in Grosser's words,

the United States is in a position at least as anachronistic as the anachronism France is allegedly guilty of. In constantly reproaching General de Gaulle for his refusal to submit to a majority vote, American opinion has displayed an altogether disarmingly clear conscience, in view of the American inability even to conceive of the fact that true Atlantic equality would require American submission to majority decisions. The incomprehension here is 
total, for American leaders and the American public find it inconceivable that the United States should lose its full sovereignty in matters of decision

For de Gaulle, France's central objective was neither unrealistic nor undesirable. He had been the first to formulate that objective while he headed French government in 1944-46, and since that time support of his view had grown. By 1958, he

was not untypical, but on the contrary characteristic, of Frenchmen and of many other Europeans in wishing to diminish political and strategic dependence on the United States as soon as economic dependence was no longer a fact. 16

And circumstance was on his side, for economic dependence had in fact greatly decreased by 1958. "De Gaulle not only desired the revival of France: he rightly saw that it was happening." 17 Contrary to what has often been assumed abroad, French economic recovery, "Though overshadowed by the crises of colonial wars and by weak, shifting Governments," was solidly underway by $1958 .{ }^{18}$ To the credit of the Monnet Plan, not de Gaulle, a new mood of innovation and belief in progress also pervaded French industry,

\section{p. 135. \\ ${ }^{15}$ Grosser, French Foreign Policy Under de Gaulle, \\ ${ }^{16}$ Peter Calvocoressi, International Politics Since} 1945 (New York: Frederick A. Praeger, 1968), p. 135.

17 Ibid., p. 133.

${ }^{18}$ Ardagh, The New French Revolution, pp. 6-7. 
playing a vital role in the French revival. "When de Gaulle returned to power in 1958 , the recovery of industry was well advanced and output was rising rapidly."19

France had rebuilt her ruins and she had regained much of her self-esteem by 1958. This change offered a new freedom of perspective in reviewing the Atlantic Alliance. And, after the Algerian war was concluded in 1962, de Gaulle's Preedom to act was also greatly increased. ${ }^{20}$ Greater independence was no longer an impossible dream. Why did it gain popular support?. As has already been mentioned above, the later events of the Fourth Republic--the Suez affair and the Algerian war--convinced a growing number of Frenchmen that reliance on the United States did not necessarily guarantee the success of policies believed to be vital to French security.

And then, from a strategic point of view, dependence was no longer an entirely satisfactory solution. In the case of a nuclear war, an overwhelming majority of Frenchmen preferred by 1958 to remain neutral. ${ }^{21}$ Not without reason. Raymond Aron, in 1963, explained the French concern:

To begin with, European cities are open to strikes by medium range missles, of which the Russians have

${ }^{19}$ Ibid., pp. $6,15$.

${ }^{20}$ Duroselle, "De Gaulle's Designs for Europe and the West," p. 173.

21 Merritt and Puchala, eds., Western European Perspectives on International Affairs, p. 224. 
a large number, while cities in the United States can be hit only by ICBMs, still relatively rare according to the United States experts. Furthermore, raising the atomic threshold might, in layman's language, mean that war could be fought on European soil and devastate that continent while the territories of both the United States and the Soviet Union were spared out of a desire strategic or moral, to prevent extreme escalation. 22

There was a further strategic consideration: the American deterrent remained almost exclusively under American command, an arrangement Americans were not easily persuaded to change. To General de Gaulle, "Atlantic interdependence" appeared to be "sheer window dressing, barely veiled hypocrisy designed to camouflage Europe's reduction to political vassalage by the United States in the guise of protection." 23 The French concern over her inequality in decision making was not simply a sign of frustration or humiliation at her less prestigious position. The Cuban missle crisis of 1962 , in which France was in reality only kept informed of the evolution of events, made it clear that France could become involved in a nuclear war without her own choosing--without even participating in the decisions that brought the war about.

The advantages of dependence were not easily discerned. American national interests took precedent over those of

${ }^{22}$ Raymond Aron, The Great Debate: Theories of Nuclear Strategy, trans. by Ernst Pawel, Anchor Books (Garden City, New York: Doubleday \& Company, Inc., 1965), pp. 76-77.

${ }^{23}$ Ibid. , pp. $168,169$. 
France. And, when considering the East-West conflict, the "protection" offered by the Atlantic Alliance could be seen as either irrelevant or dangerous: if the Communist threat had passed, protection was no longer needed; if it had not, the Alliance was more apt to make a target of France than provide a shield--and that with France having little voice in the matter. Even had a substantial movement in France not existed ever since the war to re-establish French independence and leadership, there would have been serious reasons by the early sixties for reconsidering France's dependent role vis-a-vis the United States.

The point is that de Gaulle was not needed in order to make these problems evident to the French. Even less was he voicing only personal concerns when he spoke out on these issues. Hather, de Gaulle's long-range goals were anticipated by the French; his own conception of a nation's rights and his analysis of the world situation provided a philosophical basis for what the French already believed.

De Gaulle's fundamental foreign policy goal after taking office in 1958 was "to achieve equality within the Alliance, while awaiting the day when the world will no longer be divided into two blocs." 24

Considering first his insistence on French equality, in de Gaulle's concept, France as a great nation must have ${ }^{24}$ Grosser, French Foreign Policy Under de Gaulle, pp. 118-19. 
the freedom to follow its own interests. This view basically disagreed with the idea of American leadership in a "Grand Design" policy. Henry Kissinger, one American observer who has recognized the divergence in the two positions, comments:

Consequently, the dispute between France and the United States centers, in part, around the philosophical issue of how nations cooperate. Washington urges a structure which makes separate action physically impossible by assigning each partner a portion of the over-all task. Paris insists that a consensus is meaningful only if each partner has a real choice. Therefore, each ally must--at least theoretically--be able to act autonimously. 25

By stressing the importance of nationalism, de Gaulle was not opposing the coordination of Western policies. "Convinced that only those capable of assuming responsibility can form meaningful associations, he can logically affirm his faith in the Atlantic Alliance while insisting on the identity of Europe and the uniqueness of France." 26 A political unit that means nothing to itself can have no meaning to others. On this basis, de Gaulle sought real participation for France in the Atlantic Alliance.

His view again differed significantly from that of the United States over the issue of bipolarity:

In General de Gaulle's view, it is true that the East-West conflict exists, but it will not be eternal, and nothing must be done that would prevent a

${ }^{25}$ Henry A. Kissinger, The Troubled Partnership: A Reappraisal of the Atlantic Alliance, Anchor Books (Garden City, New York: Doubleday \& Company, Inc., 1966), p. 46. 26 Ibid., p. 62 . 
change on the world chessboard in case of a détente in the East-West conflict. In the American view - . the East-West conflict will constitute the major axis of world politics for a long time to come: to worry about what will happen afterward is in the realm of prophecy and not politics. 27

This last quotation from Grosser suggests what is perhaps the most fundamental disagreement between the Gaullist outlook on the international scene and the American. De Gaulle always maintained a historical perspective. It is a historical lesson that nations outlive ideolgjes, that conflicts end, and de Gaulle did not forget to apply this lesson to the East-West conflict. When he spoke, for instance, of "the Atlantic Alliance currently necessary to the defense of the free world" in his message to Parliament on Decenber 11, 1962, he was not prophesying but expressing an awareness of the process of change. 28

But it is just this kind of awareness that is foreign to the American mentality. One might say that Americans do not think historically. If it is one of the great weaknesses of the Marxian interpretation of history to bring the dialectic process to an end, it is the even greater weakness of the American interpretation never to acknowledge the historical dialectic. How does this relate to American foreign p. 114 .

27 Grosser, French Foreign Policy Under de Gaulle,

${ }^{28}$ Note quoted in ibid. 
policy? Earlier it was suggested that the two principal goals of American foreign policy since the war have been the defense of peace and anti-Communism. Neither of these goals could have taken the form they did without American resistance to historical thinking.

Consider first the American conception of peace:

The United States has a tendency to believe that peace and stability are "natural." Crises must, therefore, be caused by personal ill-will rather than by objective conditions. If tension persists, it is because Communist leaders continue to be unreasonable; it can be alleviated by establishing an atmosphere of trust and good personal relations or

This view applies no less to the United States attitude toward de Gaulle than it does to East-West relations. And it completely ignores historical perspective; stasis is the constant, change an invading and evil force. American policy envisages a world "where all conflict has ended and nations live under 'the rule of law." 30 This might be an admirable ideal, but Americans have yet to distinguish between the ideal and reality. Here, it might be added, de Gaulle's view has been more historical. Peace to him "is achieved not by personal reconciliation but by the establishment of a more stable equilibrium." 31

Again, the connection between anti-historical thinking

${ }^{29}$ Kissinger, The Troubled Partnership, p. 58. $30^{\text {Ibid. }}$

${ }^{31}$ Ibid. , p. 6. 
and the pre-eminent position of anti-Communism in American foreign policy seems so basic that one wonders whether the latter could exist without the former $\cdots-$ or at least whether it could be taken with such seriousness. The radical presentmindedness of the American view--the unwillingness to look back or to look ahead--lends to the view of international relations suggested by Henry Kissinger in the quote above and by Walter LaFeber at the beginning of this chapter: crises are brought about, not by historic events such as the clash of national interests, but by individuals bearing personal antipathy toward the United States. Communist leaders proved to be the most reliable and convenient antagonists, but the General as well was seldom above suspicion.

De Gaulle's historical perspective removed him from one-diminsional ideological cominitments. He believed that the bipolar structure had originated at a specific date (the Yalta Conference) and he was equally convinced that it would not continue forever. Whatever misjudgements he might have made here, he at least had the historical acuity to recognize that the latest major world division did not ipso facto infer a final world ordering. This recognition, however obvious it might seem, was by no means trivial since he made it the basis for evaluating the state of world affairs. It gave him the freedom and the incentive to plan for France's future at a time when most world leaders' concerns were with 
day to day events. For American policymakers, on the other hand, the bipolar order was more readily seen as permanent. A central policy of anti-Communism confirmed and perpetuated that perraanence.

All this suggests basic differences in the French and American positions, botin in national interests and in perspective. The primary concern of this paper has been with Franco-American discord under the Fourth kepublic, but it does not seem irrelevant to have moved, however briefly and generally, beyond 1958. The central policies and perspectives on both sides indicate continuum rather than movement in new directions, but at the same time a sharpening of focus so that the conflicts of the fifties can be more readily understood. Certainly American concern with Communism did not begin in the sixties; neither did French concern over its independence versus American "leadership" begin at the time of de Gaulle's return to power.

How does one pin down the sources of Franco-American conflict? Does one begin with Roosevelt's French policy of 1944, with his personal animosity for de Gaulle and his withholding of recognition, as Brinton suggests? ${ }^{32}$ But that would imply that criticism of American diplomacy should have eased during the Fourth Republic when the General had disappeared from public view--a time in which anti-Americanism 32 Brinton, The Americans and the French, pp. 78-79. 
was developing solid foundations. Or does one look, with LaFaber, to the disagreewent over Germany's position in the postwar world? ${ }^{33}$ As Grosser points out, however, "we (the French)'go virtually from 'no enemy, but Germany,' in 1944, to 'no friend, but Germany,' in 1958." Germany and Algeria, the two countries with which France shared the most suffering, were in the sixties the two countries with which France maintained privileged relations. ${ }^{34}$ Yet this transformation in Franco-German relations did not see a parallel in FrancoAmerican relations.

The search for roots is perhaps a pointless game. If one insists, however, on locating the source of FrancoAmerican discord, it is not likely to be found in any specific event or series of events. Of the EDC debate over German rearmament, which seemed to be tearing France apart in 1954 and to threaten permanent damage to Franco-American relations, what was remembered by 1958 ? It is in the separate attitudes, rather, out of which grew the postwar policies of France and the United States to combat Communism--that the real roots of discord might be discovered.

It is not just that interests conflicted but that, as differences became more marked, the two countries were not

${ }^{33}$ LaFeber, America, Russia, and the Cold War, 1945-1966, pp. 9, 48-52.

\section{${ }^{34}$ Grosser, French Foreign Policy Under de Gaulle,} pp. 6,45 . 
equally free to follow their own concerns. Specifically, France found that she was not as free as she might have supposed of American guidance. Being dogmatically committed to its ideology (or counter-ideology) and thus working in the realm of absolute rather than relative truths, the United States for its part could not allow--could not conceive of--France or any other ally having separate interests. Such interests could only indicate conspiracy or misdirection. The accusations and hostility directed at de Gaulle, often for nothing more than his courage to speak up for French interests, reflect the extent of American incomprehension.

Anti-Americanism became more explicit under de Gaulle's foreign policy but it certainly aid not begin there. It is the weakness of American thinking that would hold the personality of the General responsible for the disintegration of Franco-American relations. Disintegration was inevitable perhaps from the moment the United States assumed that French interests would naturally and invariably coincide with American interests--that is to say, from the beginning. 


\section{A SELECTED BIBLIOGRAPHY}

"A Letter From Ike." Time. April 21, 1958.

Alphand, Hervé. Correspondence with the Author. May 13, 1970.

Ardagh, John. The New French Revolution. Harper Colophon Books. New York: Harper \& kow, Publishers, 1969.

Aron, Raymond. Correspondence with the Author, April 7, 1970.

- France, Steadfast and Changing: The Fourth to the Fifth Republic. Cambridge: Harvard University Press, 1960.

- The Great Debate: Theories of Nuclear Strategy. Translated by E'rnst Pawel. Anchor Books. Garden City, New York: Doubleday \& Company, Inc., 1965.

and Heckscher, August. Diversity of Worlds: France and the United States Look at Their Common Problems. New York: Reynal \& Company, 1957.

Aron, Robert. France Reborn, the History of the Liberation. Translated by Humphrey Hare. New York: Charles Scribner's Sons, 1964.

Ball, George W. The Discipline of Power: Essentials of a Modern World Structure. Boston: Little, Brown and Company, 1968.

Barraclough, G. Survey of International Affairs: 1956-1958. Issued under the Auspices of the Royal Institute of International Affairs. London: Oxford University Press, 1962.

Bloch, Marc. Strange Defeat. Translated by Gerald Hopkins. New York: W.W. Norton \& Company, Inc., 1968.

Bourgès-Maunoury, Maurice. Correspondence with the suthor. April 16, 1970.

Brinton, Crane. The Americans and the French. Cambridge: Harvard University Press, 1968. 
Calvocoressi, Peter. International Politics Since 1945.

New York: Frederick A. Praeger, 1968.

Cate, Curtis. "Ambassador Murphy's 'Good Offices." The

New Republic. April 21, 1958.

1958

"NATO and North Africa," The New Republic. May 5,

Commentary. November, 1963.

Congressional Record. 85th Cong., 1st sess., vol. 103, pt. 8, July 2, 1957 .

Delbecque, Léon. Correspondence with the Author. April 25, 1970 .

Department of State. Foreign Relations of the United States, Diplomatic Papers, 1944, I. Washington: United States Government Fringing office, 1965.

- Foreign Relations of the United States, Diplomatic Papers, 1944, III. Washington: United States Government Printing office, 1965.

- Foreign Relations of the United States, Diplomatic Papers, 1945, IV. Washington: United Stutes Government Printing office, 1968.

DePorte, A. W. De Gaulle's Foreign Policy, 1944-46.

Cambridge: Harvard University Press, 1968.

Doty, R. C. "As NATO Meets: What Europe Says of Us." The New York Times Magazine. December 15, 1957.

Duroselle, Jean-Baptiste, et al. "Changes in French Foreign Policy Since 1945." In Search of France. New York:

Harper \& llow, Publishers, 1963.

"De Gaulle's Designs for Europe and the West."

Changing East-West. Relations and the Unity of the West:

Papers Presented to the European-American Colloquium,

May 1 and 2,1964 , at the Washington Center of Foreign

Policy lResearch, School of Advanced International

Studies, The Johns Hopkins University. Edited by

Arnold Wolfers. Baltimore:... Johns Hopkins Press, 1964.

Feis, Herbert. Churchill, Roosevelt, Stalin, The War They Waged and the Peace They Sought. Princeton: Princeton University Press, 1967. 
Fisher, Roger, ed. International Conflict and Behavioral Science: The Craigville Papers. New York: Basic Books, Inc., 1964 .

"France's Misdirected Fury." The Economist. April 19, 1958.

"French Pride and Prejudice." The Economist. November 23, 1957 .

Funk, Arthur. Charles de Gaulle: The Crucial Years, 1943-44. Norman; University of Oklahoma Press, 1959.

Furniss, Edgar. France, Troubled Ally: De Gaulle's Heritage and Prospects. New Yurk: Published for the Council on Foreign Relations by Harper \& Brother, 1960.

Grandual, Gilbert. Correspondence with the Author. May 12, 1970.

Grosser, Alfred. "Comnodités de l'Anti-Americanisme."

Le Monde. November 25, 1958.

- Correspondence with the Author. April 6, 1970.

- France Defeats EDC. Edited by Daniel Lerner and Raymond Aron. New York: Fredrick A. Praeger, Inc., 1957 .

- French Foreign Policy Under De Gaulle. Translated by Lois Ames Pattison. Foreword by Stanley Hoffmann. Boston: Little, Brown and Company, 1967.

- La Quatrieme Republique et sa politique extérieur.

Hoffmann, Stanley, et al. "Paradoxes of the French Political Community." In Search of France. New York: Harper \& Row, Publishers, 1963.

Hughes, H. Stuart. The Obstructed Path: French Social Thought in the Years of Desperation, 1930-1960. New York: Harper \& kow, Publishers, 1969.

Journal Officiel. Débats Parlementaires. Assemblée Nationale, April 15, 1958.

Débats Parlenentaires. Assemblée Nationale, April 15, 1958.

Kissinger, Henry A. The Troubled Partnership: A Reappraisal of the Atlantic Alliance. Anchor Books. Garden City, New York: Doubleday \& Company, Inc., 1966. 
Klein, Burton II. Germany's Economic Preparations for War. Cambridge: Harvard University Press, 1959.

Kolko, Gabriel. The Politics of War: The World and United States Foreign Policy, 1943-1945. New York: Random House, 1968.

Kulski, W. W. De Gaulle and the World: The Foreign Policy of the Fifth French Republic. Syracuse: Syracuse University Press, 1966.

Lacoste, Robert. Correspondence with the Author. April 21, 1970 .

LaFeber, Walter. America, Russia, and the Cold War, 19451966. New York: John Wiley and Sons, Inc., 1967.

Le Monde. February 11, 25, March 7, 15, April 14, 15, 17, 1958.

Leuthy, Herbert. France Against Herself. Translated by Eric Mosbacher. New York: Meridian Books, Inc., 1955.

Merritt, Richard L., and Pushala, Donald J., eds. Western European Perspectives on International Affairs: Public Opinion Studies and Evaluations. New York: Frederick A. Praeger, Publishers, 1968.

Michel, Henri. Histoire de la résistance. Paris: Presses Universitaires de France, 1958.

Mollet, Guy. Correspondence with the Author. April 23, 1970 .

Morazé, Charles. The French and the Republic. Translated by J.-J. Demorest. Ithaca, New York: Cornell University Press, 1958.

Morice, André. Correspondence with the Author. April 10, 1970 .

Murphy, Robert. "Basic Elements in United States Foreign Policy." The Department of State Bulletin, XXXIX 1970.

Correspondence with the Author. February 12,

- Diplomat Among Warriors. Garden City, New York: Doubleday, 1964. 
Murphy, Robert. "Review of Recent Anti-American Demonstrations." The Department of State Bulletin, XXXVIII (June 9, 1958).

The New York Times. February $8,9,11,14,15,16,17,19$, $24,25,27$, March 1, 11, 14, 17, 18, 19, April 12, 13, $14,17,1958$.

Pflimlin, Pierre. Correspondence with the Author. April 13, 1970 .

Philip, André. Correspondence with the Author. April 8, 1970 .

- France Defeats EDC. Edited by Daniel Lerner and Raymond Aron. New York: Frederick A. Praeger, Inc., 1957 .

Pickles, Dorothy. Algeria and France: From Colonialism to Cooperation. New York: Frederick A. Praeger, 1963.

Pineau, Christian. Correspondence with the Author. April 10,1970 .

Schoenbrun, David. The Three Lives of Charles de Gaulle. New York: Atheneum, 1966.

Serfaty, Simon. France, De Gaulle, and Europe: The Policy of the Fourth and Fifth Republics toward the Continent. Baltimore: The Johns Hopkins Press, 1968.

Smith, Gaddis. American Diplomacy During the Second World War, 1941-1945. New York: John Wiley and Sons, Inc., 1967 .

Soustelle, Jacque. Correspondence with the Author. March 31,1970 .

Stimson, Henry L., and Bundy, McGeorge. On Active Service in Peace and War. New York: Harper, 1948.

Suffert, Georges. "Entretien: Maurice Duverger." L'Express. March 5, 1964.

Taylor, A. J. P. The Origins of the Second World War. 2nd ed. Greenwich, Conn.: Fawcett Publications, Inc., 1961.

Thomson, David. Democracy in France Since 1870. 4th ed. New York: Oxford University Press, 1964. 
Turenne, Henri de. "Grand Subject." The New York Times Magazine. September 12, 1965.

United Nations. Security Council, Thirteenth Year, Supplement for January, February and March, 1958. Letter dated 14 February 1958 from the Representative of France to the President of the Security Council, S/3954.

- Security Council, Thirteenth Year, Supplement for January, February and March, 1958. Letter dated 13 February 1958 from the Representative of Tunisia to the President of the Security Council, S/3952.

The War Memoirs of Charles de Gaulle: Salvation, 1944-1946. Translated by Richard Howard. Vol. III. New York: Simon and Schuster, 1960.

The War Memoirs of Charles de Gaulle: The Call to Honor, 1940-1942. Translated by Jonathan Griffin. Vol. I. New York: The Viking Press, 1955.

The War Memoirs of Charles de Gaulle: Unity, 1942-1944. Translated by Richard Howard. Vol. II. New York: Simon and Schuster, 1959.

Werth, Alexander. De Gaulle: A Political Biography. Baltimore: Penguin Books, Inc., 1967. 1960 The De Gaulle Revolution. Robert Hale Limited, - Prance, 1940-1955. Kobert Hale, Ltd., 1956.

White, Dorothy Shipley. Seeds of Discord: De Gaulle, Free France and the Allies. Syracuse: Syracuse University Press, 1964.

Wright, Gordon. France in Modern Times: 1760 to the Present. Chicago: Rand McNally \& Company, 1960.

- The Ordeal of Total War, 1939-1945. New York:

Harper \& Row, Publishers, 1968. 


\section{APPENDIX}

On the following pages I have included the letters that I quoted from or, for one reason or another, found interesting or valuable. I regret that two letters which have been particularly helpful in shaping my opinion--those of MM. Michel Debré and Pierre Mendès-France--could not be quoted or included here by request of their authors. I had very much hoped to receive a letter from M. Gaillard and the letter of M. Bourgès-Maunoury has been entered only because it indicates that Gaillard planned to write. His unfortunate death this spring, however, came before he was able to reply and closed the door on the possibility of discovering his impressions of the good offices mission. Of the men whose letters. I considered to be of greatest value, the political positions of Jacque Soustelle and André Morice have already been indicated in the text. Christian Pineau was, at the time, the Socialist Minister of Foreign Affairs. Léon Delbecque was a Gaullist on the staff of Jacque ChabanDelmas, the Minister of Defense. He provided a link between the discontented military chiefs and the revolutionary French in Algeria. André Philip was a Socialist and a devoted "European"; Pierre Pflimlin was also a "European" and chairman of the Movement républicain populaire (MRP). He pulled together a short-lived government in May that stepped aside 
for de Gaulle after the crisis of May 13.

The questions to which the Frenchmen responded were as

follows :

1). Should the unpopular reception of the good offices mission be attributed entirely to French attitudes which predated the bombing of Sakiet (in particular, the suspicion that the United States would attempt to involve itself in the Algerian situation, a strictly French problem), or did the image of $\mathrm{Mr}$. Murphy himself influence French opinion of the good offices? Were his activities from the Occupation period remembered? Did his appointment serve to confirm doubts about the mission? Did it create new doubts? Might someone else have engendered more confidence?

2) Had the good offices mission been handled differently, or had someone other than Mr. Murphy represented the United States, might the Gaillard Govern-ment have resolved its differences with Tunisia?

Could it have eventually solved the Algerian problem? Can Mr. Murphy or the good offices mission reasonably be held responsible for contributing, directly or indirectly, to the fall of the Fourth Republic?

Herve Alphand is an exception. He was the Prench Ambassador to the United States and Dulles had conferred with him about the Sakiet borabing. I was curious to know whether Dulles had discussed various possible candidates with him before making the Murphy appointment. As his letter indicates, however, Dulles had not. From Murphy I wanted to know (1), how he came to be appointed, (2), how he felt at the outset of the mission about its value and its probable success, and (3), whether he believed that groups on the Right were also involved in arousing anti-Americanism in France at the time of the good offices mission. 
MINISTÈRE

DES

AFFAIRES ÉTRANGËRES

$\mu: 196 / A R D$
RÉPUBLIQUE FRANÇAISE.

PARIS, LE 13 MAI 1970

Monsieur,

Par lettre du 10 mars 1970 , vous m'avez posó, à

propos de votre travail sur h. hobert liurphy et sa mission en Tunisie en 1958, diverses questions concernant l'attitude du gouvemement français à l'époque. Vous désiriez en particulier savoir si le gouvernerent français avait été consulté au sujet de la désignation de M. Murphy et quelles avaient été ses réactions.

J'ai 2 'honneur de vous faire savoir que le gouvernement français n'a pas été consulté par le gouvernenent des Etats-Unis avant ia nomination ce i. Uurphy et cone qu'il n'a pas eu à se poser les différentes questions mentionnées dans votre lettre.

Veuiliez agréer, lionsieur, l'assurance de ma considération distinguée.

M. Iorin Anderson

1831 S.H. Park Avenue

Portlend, Oregon 97201

POETLAND STATE UNIVEESITY

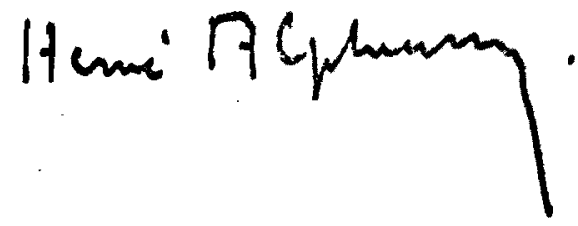

U.S.A. 
ECOLE PRATIQUE DES HAUTES ETUDES

Sclences Economiques et Socioles

Centre de Sociologie Europèenne
6. rue de Tournon, 60 (Mèd. 39.00)

( et 85.46)

PARIS, lo 7AVRIL 1970

\author{
Monsieur Lorin ANDERSON \\ PORTLAND STATE UNIVERSITY \\ Division of Social science \\ P. O. BOX 751 \\ PORTLAND, ORE $97207 /$ USA
}

Cher Monsieur,

J'ai bien reçu votre lettre du 10 mars.

II n'est pas facile de donner une réponse catégorique aux deux questions que vous me posez; les remarques suivantes traduisent mes impressions de l'époque et rien de plus; de toute manière, la mission de M. Murphy n'aurait pas réussi parce que l'opinion française soupçonnait les Etats-Unis d'intervenir dans l'affaire algérienne, considórée comme concernant exclusipunent la Frince. La personnalité de M. MURPIIY créait un obstacle supplémentaire sur la voie du succès, en raison du role qu'il avait joué pendant la guerre et de ses relations avec le Gouvernement de Vichy. Cependant, il ne s'agit là que d'un détail sans grande importance.

D'aucune manière le gouvernement Gaillard n'aurait pu régler le problème d'Algérie.

Croyez, je vous prie, à l'assurance de mes sentiments dévoués.

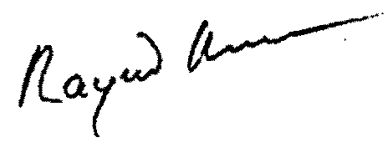

Raymond ARON 
67. RUE LA BOËTIE. PARIS VIII"?

le 16 Avril 1970

\author{
Monsieur Lorin Anderson \\ 1831 S.W. Park Avenue \\ Appartement 507 \\ PORTLAND \\ Oregon 97201
}

U.S.A.

Monsieur ,

J'ai bien reçu votre lettre du 31 mars dernier, je l'ai transmise à mon ami Fúlix Gaillard qui était Président da Conseil à l'époque des bons offices et qui està à même de répondre à vos questions d'une manière plus précise que moi-même .

Je vous prie de croire, Monsieur, à mes sentiments les meilleurs.

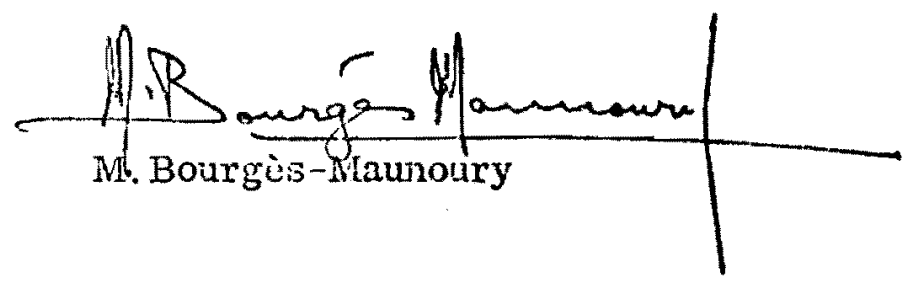


Cher Monsieur,

En reponse à votre lettre, veuillea trouver ci-aprèa quelques notes concernant la miseion "bons offices" do Monaieure MURPHY en 1958.

Ie personnel parlementaire et, bien entendu, les ministres se bourenajent du rBle qu'avait joue Nonsieur MURPHP, en 1942, en Afrique du Irord. I'opinion publique l'avait oublis. Ce n'est done pas la présence de Monsieur lURPHY la tete do la misoion de bons offices, qui explique la mécience d'une partie de I'opinion publigue et l'hostilité d'une autre partio a l'égard de cette misbion.

Bien avant le bombardement de SAKIET, la plupart des Francais considéraient lonsieux BOURGUIBA - qui hébergeait en Tunisie une forte arzée du F.I.N. alérien et laissait cette amee attaquer les positions françaises de la frontière - commo le complice eu moins pacsit de la rébellion alérienno. En fait, Monsieur BOURGUIBA Etait méme cocusé de belliguranoo. Il importeit donc peu que ce fat Nonsieur MUPHY qui intervint dans le differend frenco-tunisien. Nimporte quel autze médiateur aurait, dans les cireonstances d'alors, suscité des réations somblables.

Il est difficile de diré gi, differemont menée, la miabion NURPHY-BEEIEY aurajt réuasi è apaiser la querelle francotunisionne. I'un des problèmes essentiels était en effet le rétablissement d'une situntion nomale la frontière. llonsieur MURPFY ne pouvait résoudre un tel probleme alorg que Monei eur BOURGUIBA luimeme en tiait incapable. On ne roit dono par commont une misaion do bons offices aurait pu eviter de buter eur oe point.

Il est certain en outre que l'intervention de M. MURPHY ot BEBLEY fut interprétée en France come une tentative sournoibe 
dintemationalisation du conflit algerien. I'opinion, dens sa majorite, se rebellait contre une intrusion etran èere dens uno affaire qui, pour elle, était une tifaire intérieure frençaise thèse deilleurs soutenua avec persévéranoe devent 1:0.N.U. par les représentents du Gouvermement.

Prise en ce bens, on doit admettre que la misaion MURPHY a precipite la chute de la Quatrière Republique. In slaocrochant a elle, lonsieur F6lix GAILIARD a en effet donné I'impression que, mal résolu à maintenir la souveraineté frangaise sur l'Algérie, il s'engazeait par un détour dans le voie de l'abandon et de I'interdépendance dans le dowaine des Arțiires Etrangdres. Déja, au ourplus, certajus milieux politiques envisageaient le retow du General de GAULIE qui peseait pour un formo partisen de I'Algério françaibe ot de I'Indepondanco nationale.

En ooncluaion : la mission de Monsieur lMUPPHY fut un des elémonto qui permirent I'acotlération du processus de regroupement des différente courents irationaux et ausei la chuto du Gouvernement GAIIIARD. Le vide politique ot la epande orise qui s'en suivit firent le reste.

Espórant que ces éléments vous aideront dans votre travail, je vous prie d'agréer, Chex lionsieur, I'expression do mes eentimente distincués.

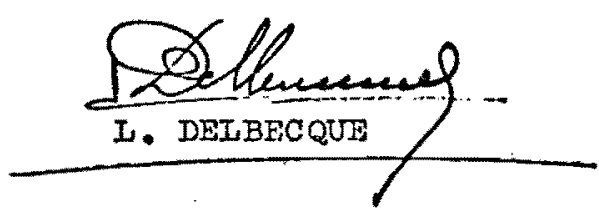


FONDATION NATIONALE

DES

SCIENCES POLITIQUES

\title{
CYCLE SUPERIEUR DETUDES POLITIQUES
}

\author{
PARIS, LE _- E AVril 1970
}

27. RUE SAINT-BUILLAUME (70)

Cher lionsieur,

Te vous remorcie de votre lettre. J'evove que ce que fo dis dans mon

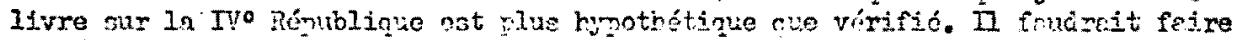
une étude de prosse et quolmues intervievs de perso ralitis.

Wn tout cos, j'aj encors rodit is mon cours cette annce olte je

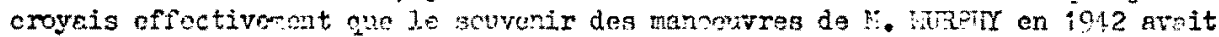
été un hordicap supnzenentrire nour la mission de bons offices.

Votre deuricome ouestion us pot rocovoir une róronso notito, bn en ost

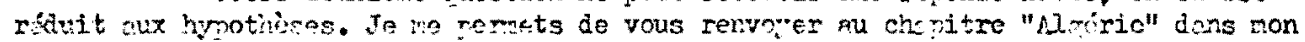

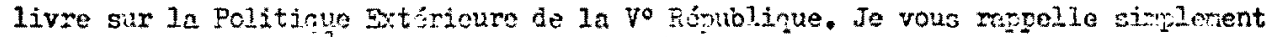

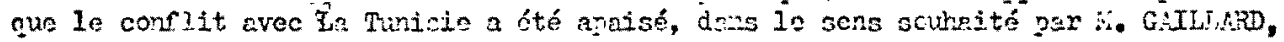

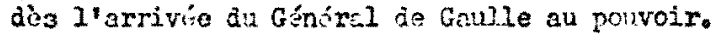

très ferme.

Finilenent ma roponse a votre toute derniere cuestion est un oui

Je voun prie de croire, cher lonsicur, à mes meillours sortinonts.

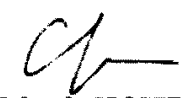

Alfred G:OSSER

$\because$ Iso-in :

1831 S.7. Fank Avenue, hpt $f 507$

Ecoutin, Oregon 97201

U.3.A. 
COMPAGNIE

DES

PARIS, le 12 ilai 1970

MESSAGERIES MARITIMES

12, DOULEVARD DE LA MADELEINE

LE PRESIOENT

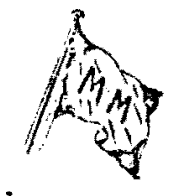

Cher Monsieur,

Je p'excuse de ne pas avoir répondu plus tot à votre lettre du 31 Vars 1970 , mais je ne revieris que saintenant d'un grand voyage en Afrique du Sud.

S1, du fait des fonctions que j'ai exercées au Maroc, je suis assez compétent en ce qui concerne les affaires chérifiennes, je ne le sujs pos du tout en ce qui concerne les affaires tunisiennes.

Ce que je crois c'est que le choix de Nonsieur liurphy a l'époque de Sakiet n'a pas été heureux. hais ce que je crois également c'est que, de toute fagon, aucur des gouvernements de la IVe République n'aurait été capable, autrement que par l'octroi de I'indépendince, de régler I'aflaire tunisienne.

Le Maroc et la Tuisie ayant obtenu leur inópendance, le problème de l'affuire d'Algérie ne pouvait pas etre a mon avis réglé autrement qu'il l'a été. L'exceptionnel mérjte du Général de Gaulle est d'avoir pu accorder son indépendance à l'Algérie sans qu'il en résulte en mótropole des troubles extrevernent graves, tout en adoptant des dispositions aui ont permis de refeler dans les moins mauvaises conditions possibles le très sérieux probleme du reclassement, en métropole, des français d'Algérie.

Je vous prle d'agréer, cher honsieur,

Monsieur Lor 1n ANDERSON

1831 S. $H$. Park Avenue, Apt. 507

PORTLAND

OREGON 97201

U.S.A.

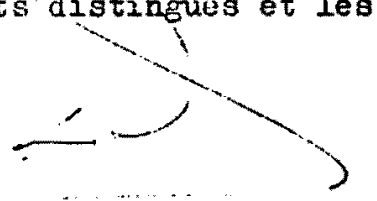
l'expression de mes sentiments' meilieurs.

Gilbert Grandval. 
PaEsident du CONBEIL

OENEAAL OE LA DORDOCHE

AMCIEN MtNISTRE

MAIAE D.AZERAT

$\mathrm{RL} / \mathrm{CA}$

,Cher Munsieur,

Les questions que vous me posez dans votre

Lettre du $3 I$ Mars ne sont pas de mon ressort.

Fortoment retenu à ALGER par les exigences

concretes d'une terrible charge: faire vivre et achominer

vers la paix un pays de Io millions d'habitants formé

de cornmunautés ethnigues violemment opposées, je n'ai

pas connu la mission MURPHY.

M. MURPIY étalt en rapport direct avec le Prési-

dent du Conseil des Ministres, M. Fél1x GAILLARD

Ministre des Affaires Etrangères; il a vupen plus,de nom-

breuses personnalités de son cholx.

Peut-ôtre aurait-il pu me rencontrer avec

profit pour lui et pour mol. Il ne 1 'a pas fait. Je le

regrette et me suis demandé alors si les raisons de son

attitude ne devaiont pas être recherchées dans une igno-

rance voulue de certains aspects de la réalité Algérienno

et un parti pris délibéré.

- Veulilez agréer, Cher Nonsieur, avec mes.

sincères regrets, l'expression de thes sentiments très

distingués.

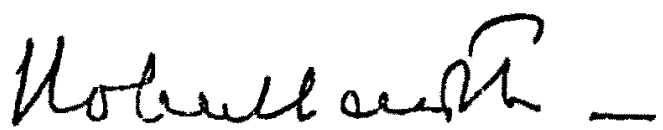

Monsieur Lortn ANDERSON

I83I S.W Park Avenue, Apt. 507

PORTLAND- OREGON $9720 I$ 


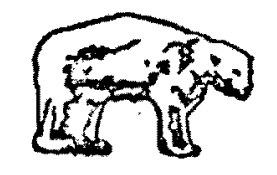

\title{
Office Universitaire de Recherche Socialiste \\ 86. rue de Lllle - PARIS (7०) - Tél. 555.08.60
}

\author{
Paris, le 23 avril 1970
}

Cher Monsieur;

J'al bien reçu votre lettre et regrette très vivement de ne pouvoir vous apporter quelque information valable dans votre enquéte.

Je n'appartenais pas au gouvernement de 1'époque et n'ai pas eté informe des difficultes rencontrées par la mission de M. Murphy.

Le seul jugement que je puisse formuler en tant que parlementalre est qu'jil ne serait pas rafsonnable de tenir $M$. Murphy ou la mission si peu que ce sojt responsable lans la suite des evènements et plus particulièrement dans la chute de la Ivème Republique.

Veutllez croire, cher Monsieur, en mes meilleurs sentiments.

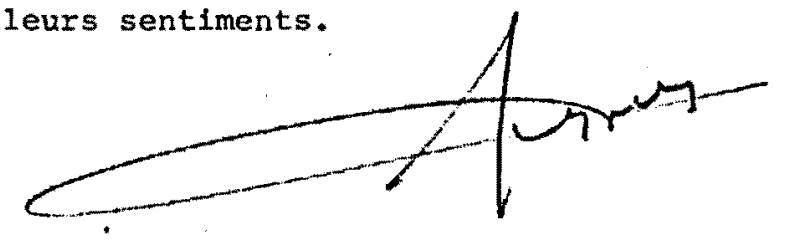

GUY MOLLET

Monsieur Lorin ANDERSON

1831 S.W. Park Ave, Apt 507

PORTLAND, Oregon 97201

(U.S.A.) 
Cher Monsiejr,

$J^{\prime}$ ai lu avec intéret votre lettre du $31 \mathrm{~m}$ ars 1970 . Je veux bien répondre brièvement, de mon mieux, aux questions que vous posez.

Tout d'abord, je suis un ami des Etats-Unis d'AmErique et ai toujours souhaité que les relations entre la France et les EtatsUnis se situent sur le plan de la plus grande amitié. Je suis allé a plusieurs reprises aux Etats-Unis, récemment encore - il y a 3 mciset je m'y trouve toujours dans des milieux particulièrement sympathiques. Done ce que je vais érire ne peut etre taxé d'inamitié envers les Etats-Unis, alors que je me sens très attaché au peuple américain.

\section{Voyons maintenant la réponse.}

Si la misgion de bons offices de $M$. Murphy s'eat traduite par un 6 chec, cela n'est pas da, selon moi, a la personnalité mème de $M$. Murphy, personnalité que nous n'avons pas a discuter. Si un autro que M. Murphy eut été placé à la tete de cette délegation, il $n^{i}$ eut pas fait mieux.

Les Français, et j'étais du nombre, ont mal pris l'immixtion des Etats-Unis cans une affaire qui était considéréce à l'époque comme une affaire française. N'oublions pas que cela venait après ane politique maladroite des Etats-Unis en Indochine, oì, au lieu d'aider les Français, les Américains ont compliqué de leur mieux tous les problèmes, alors qu'il était de notre intéret commun de travaillex ensemble. En ce qui concerne le Viet-Nam, et la suite ddes évènements l'a prouvé, les Américains ayant travaillé à chasser les Français d'Indochine, s'y sont installés et ont hérité de toutes les äfficultés présentes. 
Meme maladresse américaine dans l'affaire de Suez. Je m'en suis d'ailleurs expliqué a l'époque avec l'adjoint au Secrétaire d'Etat ì Washington. Si, au lieu d'exercer cette pression sur les Français et les Anglais pour les faire abandonner l'expédition, on nous avait laissé les mains libres quelques jours encore, non seulement le problème Nasser était règlé, máis aussi le problème de l'Algérie française. Au lieu de cela, les Américains ont fait pression sur nous pour nous faire lacher l'expédition en son beau milieu, ouvrant ainsi la porte aux difficultés au Moyen-Orient que nous connais sons depuis.

Nous savions bien, en ce qui concerne l'Algérie, que les formules de jadis n'étaient plus valables et qu'il faudiait en arriver à un accord. Mais tout ceci eüt pú etre fait sur une distance de plusieurs anrées au lieu d'être précipité et se traduire finalement par de la honte et du sang.

Dans la mission Murphy, ce n'est pas M. Murphy qui, personnellement, porte toutes les responsabilités. C'est le fait meme de cette mission qui a eté une intrusion dans nos affaires françaises et qui, tout en déclarant qu'il s'agissait d'arranger les choses, n'a fait, au contraire, que les compliquer en précipitant les evènements et en faisant passer l'affaire d'Algérie et de la Tunisie du plan français au plan international où tout ne pouvait que se dissoudre.

Voilà quelques renseignements qui, je l'espère. répondront à votre demande.

Pour conclure vous me demandez si la mission de M. Murphy a contribué directement ou indirectement à la chute de la IVè Répubilque. Je pense qu'il serait injuste de faire porter cette responsabilité à $M$. Murphy. La mission Murphy a été, si vous le voulez, un élément de flus qui a contribue à l'avènement de la Vè République en Iranee, mais elle n'en a pas été l'elément moteur ou déterminant.

Je vous prie d'agréer, cher Monsieur, l'assurance de mes sentiments les plus distingués.

Monsieur Lorin Anderson

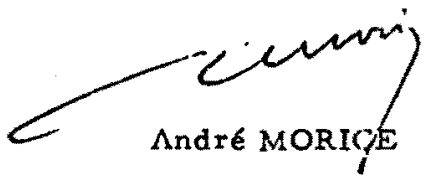

1831 S. W. Park Avenue, Apt. $\not 1 /=507$

Portland, Oregon 97201 


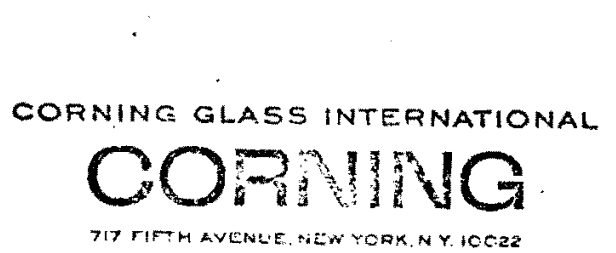
PORTLAND STATE LWNVVISTY
FACILITIES PLANINING
[ES 161970
RECEIVED FILE

ROECRT D. MUAPHY

Chairmen of the Board
7 TIFTM AVENEE, HEW YORK, NYICOZZ

February 12, 1970

Mx. Lorin Anderson

Portland State University

P.O. Box 751

Portland, Oregon 97207

Dear Mr. Anderson:

I take pleasure in acknowledging the receipt of your undated letter addressed to me at my washington address, which I have just received.

I om glad to answer the questions you put as follows:

1) I came to be appointed to the task of U.S. representative to a rood offires tean consisting of sir Harold Beeley of the British Foreign Office and myself, because the French Government had requested such an Anglo-Anerican Good Offices mission after the French Airforce had bombed the Tunisian vilage of Side Sakiet. At the time my job was Deputy Undex Secretary of State for Political Affairs, Department of State, Washington, and I was designated for this task by the then secretary of state, Dulles, and President Eisenhower.

2) Our Government was rather reluctant to assume this responsibility as that type of task is rather thankless. As in the case of most disputes a mediator enjoys the opportunity to be attaciked by both parties

3) Actualiy some members of the Gaullist group in addition to the Comminist element were vigorously opposed to foreign intervention in the matter. On my arrival in Faris I rememer being greeted by a scorching newspaper article with a byline by Michel Debre, subsequently Gaullist Prime Minister, saying in effect that Sir. Harold and I were unwelcome volunteers and the best thing we could do would be to return home leaving the French to settle their cw affairs. Up to that point they had not been very successfur.

I might add that if youl library happens to have a copy 
of a book I wrote called "Diplonet Among Warriors", it contains an account of the Tunisian affair in Chapter 27 .

With kind regards.

Sincerèly yours,

Hocerkengey

Robert Murphy

$\mathrm{RM}: I \mathrm{~b}$ 
Cher Monsieur,

J'ai bien reçu votre lettre du 31 mars par laquelie vous me demandez des renseignements sur la mission confiée en 1958 à M. Robert Murphy.

Je ne dispose que de très peu de renseignements sur cette affaire car les problèmes en question ne relevaient pas, à l'époque, de ma compétence gouvernementale. C'est donc uniquement en me basant sur le souvenir que j'ai gardé de propos recueillis à l'époque et, sous toutes réserve, que je puis faire à vos deux questions les réponses suivantes :

1) Le principe même d'une intervention des Etats-Unis dans l'affaire tunisienne était contesté par de nombreux hommes politiques français et au sein même du Gouvernement. A tort ou à raison beaucoup

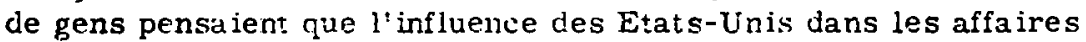
d'Afrique du Nord risquait de s'exercer au détriment des intérets français tels qu'on les conceva it à J'époque. Je ne crois pas que la personnalité de M. Murphy ait été à cet égard un facteur déterminant.

2) Il est difficile d'imaginer comment les événements auraient évolue si la mission de "bons offices" entre la France et la Tunisie avait été admise par le Gouvernement français et si elle ava it abouti à un résultat favorable. Personnellement je ne crois pas que, même dans I'hypothèse la plus favorable, la crise algérienre aura it pu être évitée. Il me paraft inconcevable que J'on puisse tenir $M$. Murphy ou sa mission comme responsable d'avoir contribué, directement ou indirectement, à la chute de la IV. République.

Veuillez agreer, cher Monsieur, l'assurance de mes sentiments les meilleurs.

Mr, Lorin ANDERSON

1831 S. W. Park Avenue, Apt. 507

PORTLAND

Oregon 97201

(U.S.A.)

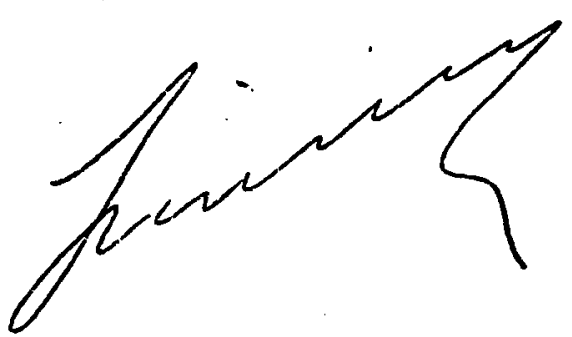


ORGAMISATION DE COOPERATION ET DE DEVELPPEMLNT ECONUMQUES

94. rue Chaidon-Lugache PARIS-XVIF

Lc Président.
ORGAMISATION FOR ECONOMIC CO-OPERATION AND DEVELOPMENT

CENTRE DE DEVITOPPEMENT DEVELOPMENT CENTRE 52765.19

Paris, le 8 Avril 1970

Cher Monsieur,

Il $\mathrm{m}^{\prime}$ est difficile de vous donner des renseignements sur une question que je $n^{\prime}$ ai pas suivie de près et qui est, par ailleurs, fort lointaine.

D'ure façon générale, il est certain que l'idée même de la mission de bons offices américains en 1958 a suscité une résistance dans l'ensemble de l'opinion publique frarcaise, à la seule exception de ceux qui. qui étaient hostiles à la politique française en Algérie. Faisant suite à $l^{\prime}$ intervention américaine, lors de $I^{\text {'expé- }}$ dition de Suez, cela apparaissait come une intervention impérialiste des Etats-Unis, dans le domaine de la politique méditerranéenne qui est, essentiellement, de compétence européenne.

La désignation de Mr. Iurphy a été un facteur d'aggravation, car tous ceux d'entre nous qui ont été en Algérie avec la France combattante, ont considéré Mr. Murfivy anmo un ativersaire de la France dont les contacts essentiels dans le pavs étaient les groupes sociaux qui avaient, préalablement, collaboré avec les Allemands. . Mais, je ne crois pas que ce facteur, queique désagréable qu'il fut, ałt été décisif. Je crois qu'à ce moment la aucune intervention extérieure à l'Europe n'aurait pu jouer un rôle positif. sentiments.

Veuillez croire, cher Honsieur, à mes meilleurs

Monsicur Lorin Anderson

1831 S.W. Park Avenue, Apt. 507

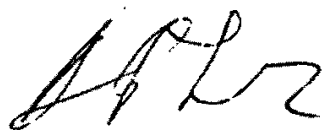

André Philip Portland, Oregon 97201

U.S.A. 
Monsteur Lorin AHDEHSON

1831 S.W. Park Ave., Apt 507

PORTLAND, OREGON 97201

Cher Monsieur,

$J$ 'ai bien reçu votre lettre did 31 mars et vous prie

de trouver en réponse une petite note sur la mission de M. MURPHY. Je crois sincèrément qu'elle correspond à la réalité historique. Je reste a votre disposition pour tous renselgnements complémentalres.

Croyez, cher Monsieur, à mes mellleurs sentiments.

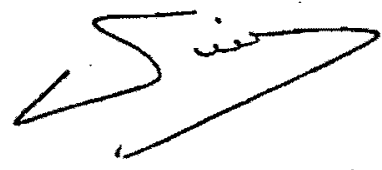


NOTE sur la mission de $H$. MURPHY dans l'affaire

algéro-tunistenne

$I$ - Il est certain que la mission de $M$. NusphY imission partagée avec un homologue britannique) a été, en 1958, mal accueilile par une partie de l'oplnion publique françalse.

La réticence à son égard tient à deux causes principales ,

- a) sa personnalité

- b) Ia situation politique du moment.

a) Les milieux gaullistes avaient conservé de $M$. MURPHY et de son activité a Ager un assez mauvais souvenir. Ils lui prêtalent une attitude hostile à la personne du général, dé fait qu'1l était le représentont du Président Rcosevelt et que son activité personnelle avait été jugés, en 1944, favorable au Général GIRAUD. Il est intéressant de souligner l'hostilité particulière de M. Michel DEBRE qui était censé, en 1958, représenter l'opinion du Général de GAULLE, contre le fait que la mission des bons offices ait été confiée a M. MURPHY.

On peut donc considérer que le choix de ce dernier a été malaórolt. encore que tout autre choix aurait comporté lui aussi des réserves.

b) Les menes milieux gaullistes se pronongaiont avec force, en 1958 , pour 1'Algérie françalse, contre ce qu'11s appelalent la "complicité tunisienne" avec le F.L.N., et pour l'exercice du "droit de suite", c'est a dire pour l'autorisation donnée aux troupes françaises de poursuivre les rebelles algériens sur le territoire tunisien ( ce qui a été fait à Sakniet).

La mission des "bons offices" leur semblait alors une atteinte a la souveraineté française, sous la forme d'une intrusion anglo-américalne dans une affalre considérée comme d'ordre purement national.

L'autre part les gaullistes avalent toujours dénoncé une soi-disant volonté des Etats-Unis de supplanter la France en Algérie. Ce qui a pu donner nalssance a cette supposition, c'ost le falt qu'à maintes reprises des dirlgeants américains ont manifesté leur crainte de voir l Union Soviétique prendre pied en Algérie, le jour où les Français serafent partis, hypothèse qu'ils considéralent comne vrai semblable.

L'élément paradoxal de cette affaire réside dans le double jeu du Général de GAULLE; Celui-ci m'avait personnellement confle, en octobre 1957 , 
qu'il étalt partisan de l'indépendarce de l'Algćrie; mals 11 comptalt, pour prendre le pouvoir, sur l'appuí des tenants de l'Algério française. L'expérience a vóriflé l'existence de ce double jeu.

II - Si la mission des "bens afflces" s'était exetcée dans d'autres conditions et avec d'autres homes, l'affaire algértenne, et par voie de conséquence l'affalre tunisienne, n'auraient pas été résolues pour autant. Le Gouvornedient GAILLARD ǵtait condamné, comne ses prédécesseurs, parce que les Français étaient las de la guerre d'Algérie encore qü' 1 ls fussent divisés sur son issue possille.

Les uns souhaitalent une soiution de force qui aurait consolidié la

présence française sans tenir conpte des aspirations des populations musuainanes. Les autres étaient partisans de l'abencion pur et simpde, négligeant ainsi les intérêts des 1.200 .000 habitants d'origine europśenne oừ viviatent en Algérie.

Au Parlement, gaullistes et cormunistes votalent ensemble contre les gouvernements $a$ la recherche d'un juste milicu.

Dans de telles conditions, la TVẹme Ripubilque était paralysée dans son fonctionnement.

Il serait done injuste et excessif d'imputer a la seule mission de M. MURPHY une chute à peu près inévitable. Il $y$ a dans l'Histoir des catalyseurs qul précipitent une évolution mais qui ne sont pos responsables du résultat final. 
“LS IDEES

Les HOMMES :

\section{Les FalTs"}

54. menuo do Mouily

92- NEUILYY-SUA $\$$ EINE

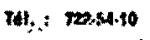

Mr. Lorin ANDERSON

1831 S.W. Park Avenue, Apt. 507

PORTLAID, Oregon 97201

U.S.A.

Cher Monsieur,

J'ai bien recu votre lettre du 10 mars et c'est bien volontiers gue j'essaierai de réponare succirictement tions. Je désire mentionner auparavant que mes relations personnelles avec Robert inurphy sont cordiales et que j'ai encore eu le plaisir de déjeuner et de converser longuevent avec lui à New York j.l y a quelque temps.

lère question : Je crois que l'attitude d'un grand nombre de membres du Parlement et de moi-même à l'égard de la mission dite de "bons offices" après Saitiet procédait avant tout de l'irritation ressentie par beaucoup devant l'incouprénensicn de nos alliés dans l'afíaire algérienne. Les campagnes de presse pro-F.I.N. aux Etats-Unis, l'accueil favorable réservé à liew Yox aux chefs terroristes, extains discours comme celui du senatoir et futur president J.F. Kennedy, la politique dite "anti-colonialiste" puechée is Wasininton et a Iondres, provuquaient en Franca de vives inquittudes. fissi blsuait-or le gouvernement Gaillard de donner i'impression qu'il s'en remettait, pour traiter un problème de cette imporuance, à des arbitres dont l'orientation connue paraissait fixée d'avance. La personine de M. Murphy n'était pas en cause (sauf peut-être chez certaiss gaullistes qui lui reprociaient cncore sa politique en 1942-43), mais bier plutot celle did Eritannique N. Beeley, dont les tendarces systématiquement pro-arabes n'étaient pas ignorées.

2ème auestion: I'épisode de la mission des bons of fices a 6té finalement d'importance mineure. Ie gouvemenent Gaillard n'aurait pas pu, avec ou sans cette mission, faire face à la situation en Afrique du liord. La détértoration du système politique français è cette époque était bien trop profonde et irrémédiable. Il serait done excessif et injuste diattribuer une responsabilité directe ou indirecte à $\mathrm{k}$. Murphy ou à la mission dana la chute du récime. Celui-ci se serait désagrégé de toute menière en raison de ses contradictions internes et de son impuissance à résoudre le $\mathrm{g}$ problènes de l'outre-mer. 
Veuillez agréer, cher Monsieur, l'assurance de mes sentiments les aeilieurs.

II9

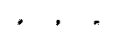

.

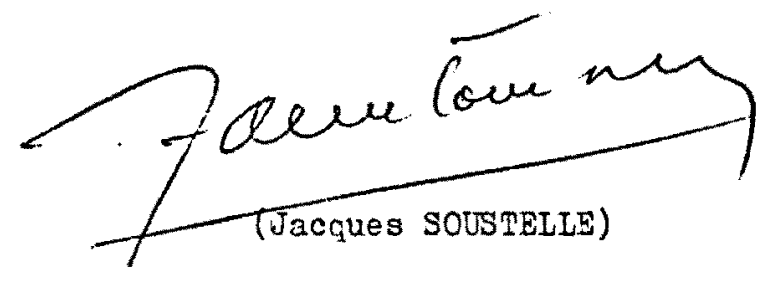

